\title{
Advances in Application of Natural Clay and Its Composites in Removal of Biological, Organic, and Inorganic Contaminants from Drinking Water
}

\author{
Rajani Srinivasan \\ Blackland Research and Extension Center, AgriLife Research, Texas A\&M University System, 720 East Blackland Road, \\ Temple, TX 76502, USA \\ Correspondence should be addressed to Rajani Srinivasan, rsrinivasan@brc.tamus.edu
}

Received 24 June 2011; Revised 1 October 2011; Accepted 8 October 2011

Academic Editor: Anuradha Mishra

Copyright ( $) 2011$ Rajani Srinivasan. This is an open access article distributed under the Creative Commons Attribution License, which permits unrestricted use, distribution, and reproduction in any medium, provided the original work is properly cited.

\begin{abstract}
Natural clays are abundantly available low-cost natural resource which is nontoxic to ecosystem. Over the recent years, research on the modification of clay to increase their adsorbent capacity to remove other contaminants from drinking water other than metals is in progress. This paper reviews the recent development of natural clays and their modified forms as adsorbing agents for treating drinking water and their sources. This paper describes the versatile nature of natural clay and their ability to adsorb variety of contaminants ranging from inorganic to emerging, which are present in the drinking water. The properties and modification of the natural clay and its significance in removing a specific type of contaminant are described. The adsorbing efficiency of the natural and modified clay in the purification of drinking water, when compared to existing technologies, materials, and methods was found to be significantly higher or comparable.
\end{abstract}

\section{Introduction}

Clean drinking water is one of the implicit requisites for a healthy human population. However, the growing industrialization, and extensive use of chemicals for various concerns, has increased the burden of unwanted pollutants of drinking water in developing and developed countries all over the world. The entry of potentially hazardous substances into the ecosystem is increasing day by day. Problems in drinking water quality include presence of excess fluoride, arsenic and natural organic matters, heavy metals, and variety of pathogens are the major causes for various water-borne diseases. Since it is not possible to prevent these chemicals from draining into the drinking water sources, the only way to maintain safer water bodies is to develop efficient purifying technologies. One such beneficial and successful procedure that has been in use is that of purification of water using natural and modified adsorbents. Several natural adsorbents are being used for treatment of contaminated drinking water and its sources. When a comparison is made with other lowcost adsorbents, the clays and their modified composites have been found to be either better or equivalent in contaminant adsorption capacity from water. Clay minerals are generally categorized into following groups: montmorillonite, smectite, kaolinite, illite, and chlorite. Montmorillonite, kaolinite, and illite are widely used because of their high specific surface area, chemical and mechanical stability, a variety of surface and structural properties, and low cost [1-4]. The price of clay is about $\$ 0.005-0.46 / \mathrm{kg}$, and the price of montmorillonite is about $\$ 0.04-0.12 / \mathrm{kg}$, which is 20 times cheaper than activated carbon $[5,6]$.

Clays are hydrous aluminosilicates broadly defined as those minerals that make up the colloid fraction of soils, sediments, rocks, and water [7] and may be composed of mixtures of fine grained clay minerals and clay-sized crystals of other minerals such as quartz, carbonate, and metal oxides. Clays play an important role in the environment by acting as a natural scavenger of pollutants by taking up cations and anions either through ion exchange or adsorption or both. Thus, clays invariably contain exchangeable cations and anions held to the surface. The prominent cations and anions found on clay surface are $\mathrm{Ca}^{2+}, \mathrm{Mg}^{2+}, \mathrm{H}^{+}, \mathrm{K}^{+}, \mathrm{NH}_{4}{ }^{+}, \mathrm{Na}^{+}$, 
$\mathrm{SO}_{4}{ }^{2-}, \mathrm{Cl}^{-}, \mathrm{PO}_{4}{ }^{3-}$, and $\mathrm{NO}^{3-}$. These ions can be exchanged with other ions relatively easily without affecting the clay mineral structure. Large specific surface area, chemical and mechanical stability, layered structure, high cation exchange capacity (CEC), and so forth have made the clays excellent adsorbent materials [8]. Both Bronsted and Lewis type of acidity in clays [9] have boosted the adsorption capacity of clay minerals to a great extent. The Bronsted acidity arises from $\mathrm{H}^{+}$ions on the surface formed by dissociation of water molecules of hydrated exchangeable metal cations on the surface. The Bronsted acidity may also arise if there is a net negative charge on the surface due to the substitution of $\mathrm{Si}^{4+}$ by $\mathrm{Al}^{3+}$ in some of the tetrahedral positions and the resultant charge is balanced by $\mathrm{H}_{3} \mathrm{O}^{+}$cations. The Lewis acidity arises from exposed trivalent cations, mostly $\mathrm{Al}^{3+}$ at the edges, or $\mathrm{Al}^{3+}$ arising from rupture of Si-O-Al bonds, or through dehydroxylation of some Bronsted acid sites. The edges and the faces of clay particles can adsorb anions, cations, and nonionic and polar contaminants from natural water. The contaminants accumulate on clay surface leading to their immobilization through the processes of ion exchange, coordination, or ion-dipole interactions. Sometimes the pollutants can be held through $\mathrm{H}$-bonding, van der Waals interactions, or hydrophobic bonding arising from either strong or weak interactions. The strength of the interactions is determined by various structural and other features of the clay mineral. van Olphen [10] has cited several types of active sites in clays, namely, (i) Bronsted acid or proton donor sites, created by interactions of adsorbed or interlayer water molecules, (ii) Lewis acid or electron acceptor sites occurring due to dehydroxylation, (iii) oxidizing sites, due to the presence of some cations in octahedral positions or due to adsorbed oxygen on surfaces, (iv) reducing sites produced due to the presence of some cations, and (v) surface hydroxyl groups, mostly found in the edges, bound to $\mathrm{Si}, \mathrm{Al}$, or other octahedral cations. Clays have been good adsorbents because of the existence of several types of active sites on the surface, which include Bronsted and Lewis acid sites and ion exchange sites. The edge hydroxyl groups have been particularly active for various types of interactions. Clays and modified clays have been found particularly useful for adsorption of heavy metals. Clays have received attention as excellent adsorbents of As, $\mathrm{Cd}, \mathrm{Cr}, \mathrm{Co}, \mathrm{Cu}, \mathrm{Fe}, \mathrm{Pb}, \mathrm{Mn}, \mathrm{Ni}$, and $\mathrm{Zn}$ in their ionic forms from aqueous medium. The adsorption capacities differs from metal to metal and also depend on the type of clay used [11].

Composites can be defined as natural or synthesized materials made from two or more materials with significantly different physical and chemical properties which remain separate and distinct at the microscopic or macroscopic scale within the material. Composites are synthesized to combine the desired properties of the materials in the composite. In nanocomposite, nanoparticles (clay, metal, carbon nanotubes, etc.) act as fillers in a matrix. Nanoparticles are particles of less than $100 \mathrm{~nm}$ in diameter that exhibit new or enhanced size-dependent properties compared with larger particles of the same material. Clay composite or nanocomposites are the materials in which major component of the material is clay in combination with other materials like metals, polymer, and so forth. Recently, the development and characterization of nanostructured polymer-clay composites has received special attention because of their advantages in comparison to the traditional polymer composites. Minimal additions of nanoclay enhance mechanical, thermal, and dimensional and barrier performance properties significantly because of the large contact area between polymer and clay on a nanoscale [12-16].

In the last few years, polymer-clay nanocomposites have received a great deal of attention, including studies on developing the composites as sorbents for nonionic and anionic pollutants [17], organic pollutants [18], anionic herbicide [19], and atrazine [20]. Chitosan-montmorillonite composites have been well characterized [21-23], and the adsorption of anionic pollutants by these composites has been investigated $[24,25]$.

This paper reviews the recent use of natural clay and its composites as an ecofriendly efficient adsorbent for removal of organic, inorganic, and pathogenic contaminants from drinking water and its sources. The major goals of the paper are

(1) to conduct comprehensive review of the literature to emphasize the importance of using clay and its modified forms as versatile, environmentally friendly adsorbents for contaminant removal from drinking water and its sources,

(2) to emphasize on the types of modification on the natural clays and the benefits of these modification on removal of major emerging contaminants of the present time,

(3) to analyze the quantitative efficiency of the individual clay and its composites in removing the various contaminants and study the effects of variable like $\mathrm{pH}$, temperature, and other conditions limiting or enhancing the adsorbent efficiencies of the clay materials.

The author believes that this paper will help in understanding the efficiency of the low-cost clay materials and their abundant availability as an alternative option to otherwise expensive and in few cases toxic treatment technologies being used globally for drinking water treatment.

An extensive literature review by the author resulted in compilation of several papers. These papers reported the use of either natural clay or their modified composites as adsorbents or technologies for removal of contaminants present in the drinking water or affecting the drinking water sources. An attempt is being made to include sufficient information like the type of natural clays used, their modification, their efficiency and variables affecting them from each work so that complete information is available to the readers. The type of analysis being used to get the maximum removal efficiency of each contaminant is also included. The complete review is being summarized in the Table 1 .

The review section is divided into following four headings on the basis of the type of contaminant removed by the clay and its composites: (1) heavy metals (2) inorganic contaminants (3) organic contaminant, and (4) pathogens. 
TABLE 1: Summary of the advances in application of natural clay and its composites in removing different contaminants from drinking water and its sources.

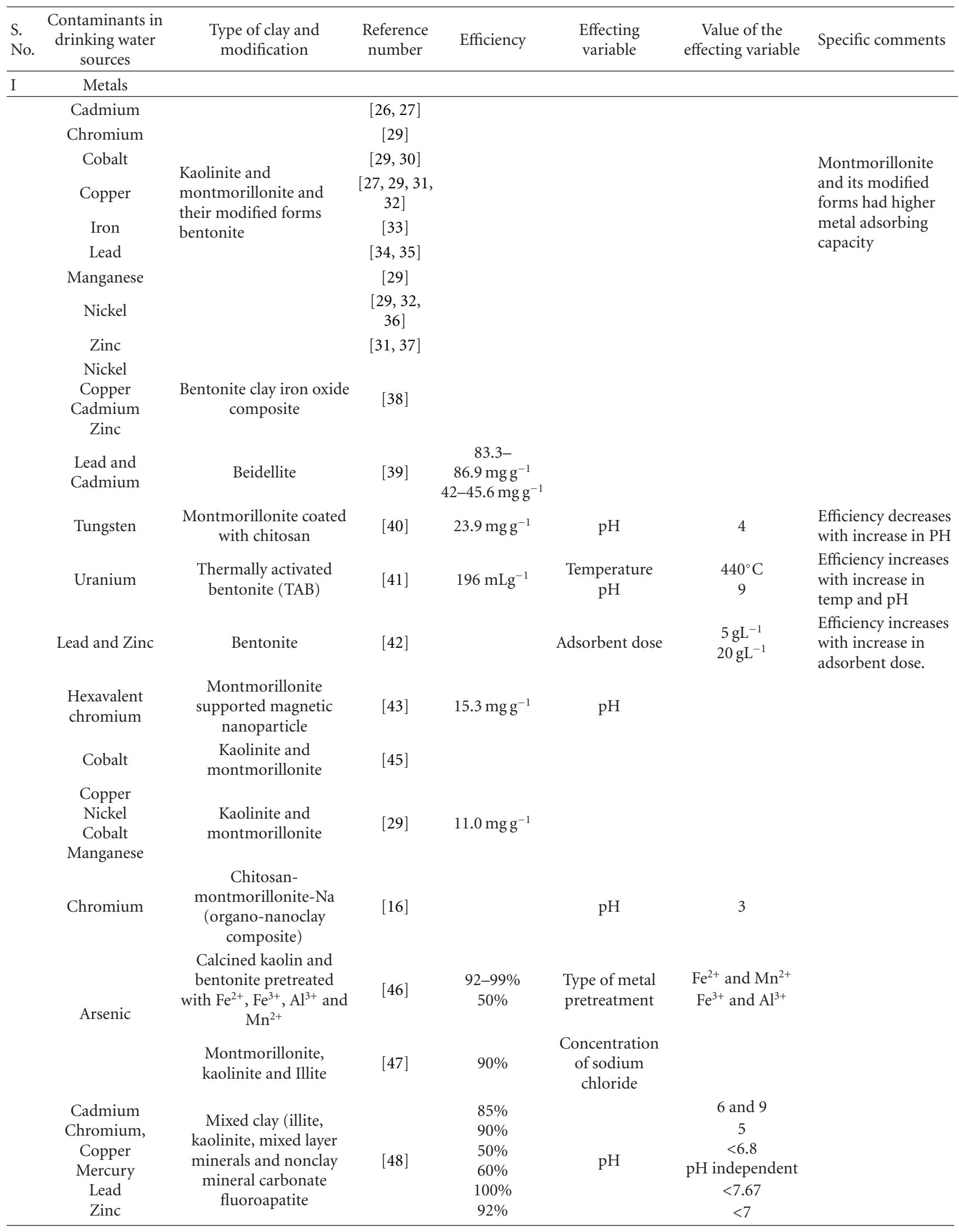


Table 1: Continued.

\begin{tabular}{|c|c|c|c|c|c|c|c|}
\hline $\begin{array}{l}\text { S. } \\
\text { No. }\end{array}$ & $\begin{array}{c}\text { Contaminants in } \\
\text { drinking water } \\
\text { sources }\end{array}$ & $\begin{array}{l}\text { Type of clay and } \\
\text { modification }\end{array}$ & $\begin{array}{l}\text { Reference } \\
\text { number }\end{array}$ & Efficiency & $\begin{array}{l}\text { Effecting } \\
\text { variable }\end{array}$ & $\begin{array}{c}\text { Value of the } \\
\text { effecting variable }\end{array}$ & Specific comments \\
\hline & Selenium & $\begin{array}{l}\text { Chitosan } \\
\text { montmorillonite }\end{array}$ & {$[52]$} & $18.4 \mathrm{mg} \mathrm{g}^{-1}$ & & & \multirow[b]{2}{*}{$\begin{array}{l}\text { Arsenite and } \\
\text { arsenate removal } \\
\text { decreased with } \\
\text { increase in } \\
\text { temperature but } \\
\text { opposite trend was } \\
\text { seen in the } \\
\text { temperature range } \\
\text { of } 45^{\circ} \mathrm{C}-65^{\circ} \mathrm{C} \text { in } \\
\text { case of arsenate. }\end{array}$} \\
\hline & $\begin{array}{l}\text { Arsenate and } \\
\text { Arsenite }\end{array}$ & $\begin{array}{l}\text { Ti-pillared } \\
\text { montmorillonite }\end{array}$ & {$[53]$} & $\begin{array}{c}\text { Greater than } \\
60 \%\end{array}$ & $\begin{array}{c}\text { Temperature } \\
\mathrm{pH}\end{array}$ & $\begin{array}{l}25^{\circ} \mathrm{C}-45^{\circ} \mathrm{C} \\
5 \text { for } \mathrm{As}(\mathrm{III}) \text { and } 3 \\
\text { for } \mathrm{AS}(\mathrm{V})\end{array}$ & \\
\hline & Lead & $\begin{array}{l}\text { Sodium } \\
\text { montmorillonite } \\
\text { clay-carboxy methyl } \\
\text { cellulose composite }\end{array}$ & {$[54]$} & & & & \multirow{3}{*}{$\begin{array}{l}\text { Increasing } \\
\text { temperature and } \\
\text { decrease in ionic } \\
\text { strength favors } \\
\text { copper adsorption. }\end{array}$} \\
\hline & Copper & $\begin{array}{l}\text { Bentonite } \\
\text { polyacrylamide } \\
\text { composite }\end{array}$ & {$[55]$} & $97 \%$ & $\mathrm{pH}$ & 7 & \\
\hline & $\begin{array}{l}\text { Lead } \\
\text { Nickel } \\
\text { Cadmium } \\
\text { Copper }\end{array}$ & $\begin{array}{l}\text { Bentonite-methylene } \\
\text { bis-acrylamide }\end{array}$ & {$[56]$} & $\begin{array}{l}1666.67 \mathrm{mg} \mathrm{g}^{-1} \\
270.27 \mathrm{mg} \mathrm{g}^{-1} \\
416.67 \mathrm{mg} \mathrm{g}^{-1} \\
222.2 \mathrm{mg} \mathrm{g}^{-1}\end{array}$ & & & \\
\hline II & $\begin{array}{c}\text { Inorganic } \\
\text { contaminants }\end{array}$ & & & & & & \\
\hline & \multirow{3}{*}{ Fluoride } & $\begin{array}{l}\text { Magnesium } \\
\text { incorporated bentonite } \\
\text { magnesium-bentonite } \\
\text { manganese-bentonite }\end{array}$ & $\begin{array}{l}{[57]} \\
{[58]}\end{array}$ & $\begin{array}{l}95.45 \% \\
\text { No significant } \\
\text { removal }\end{array}$ & Desorption & $97 \%$ & \multirow{2}{*}{$\begin{array}{l}\text { Decreases the } \\
\text { capacity of the } \\
\text { desorbed } \mathrm{MB} \text { from } \\
95 \% \text { to } 75 \% \text {. } \\
\text { Fluoride removal } \\
\text { decreases at alkaline } \\
\text { pH }\end{array}$} \\
\hline & & Lanthanum-bentonite & & $68 \%$ & $\mathrm{pH}$ & 5 & \\
\hline & & $\begin{array}{l}\text { Zirconium loaded } \\
\text { bentonite }\end{array}$ & {$[59]$} & - & $\mathrm{pH}$ & Less than 6 & $\begin{array}{l}\text { Best removal is } \\
\text { found below pH } 6 \text {. }\end{array}$ \\
\hline & Nitrates & $\begin{array}{c}\text { Calcium } \\
\text { montmorillonite } \\
\text { activated by } \\
\text { hydrochloric acid }\end{array}$ & {$[60]$} & $22.28 \%$ & Stirring time & 68 hours & $\begin{array}{l}13.74 \% \text { removal } \\
\text { was increased to } \\
22.28 \% \text { when } \\
\text { stirring time } \\
\text { increased from } 0.5 \\
\text { hours to } 68 \text { hours }\end{array}$ \\
\hline III & $\begin{array}{c}\text { Organic } \\
\text { contaminants }\end{array}$ & & & & & & \\
\hline & Dichloroacetic acid & $\begin{array}{c}\text { Bentonite-based } \\
\text { Absorptive ozonation } \\
\text { followed by catalytic } \\
\text { oxidation by } \mathrm{Fe}^{3+}\end{array}$ & {$[61]$} & $92 \%$ & Addition of $\mathrm{Fe}^{3+}$ & $5 \mathrm{mg} \mathrm{L}^{-1}$ & \multirow[t]{2}{*}{$\begin{array}{l}\text { Increase of } \\
\text { concentration of } \\
\mathrm{Fe}^{3+} \text { from } \\
0.5 \mathrm{mg} \mathrm{L}^{-1} \text { to } \\
5 \mathrm{mg} \mathrm{L}^{-1} \text { increased } \\
\text { the removal } \\
\text { efficiency from } 68 \% \\
\text { to } 92 \%\end{array}$} \\
\hline & $\begin{array}{l}\text { Carbon } \\
\text { tetrachloride }\end{array}$ & $\begin{array}{l}\text { Quaternary ammonium } \\
\text { salt-modified bentonite }\end{array}$ & {$[62]$} & $70 \%$ & & & \\
\hline
\end{tabular}


Table 1: Continued.

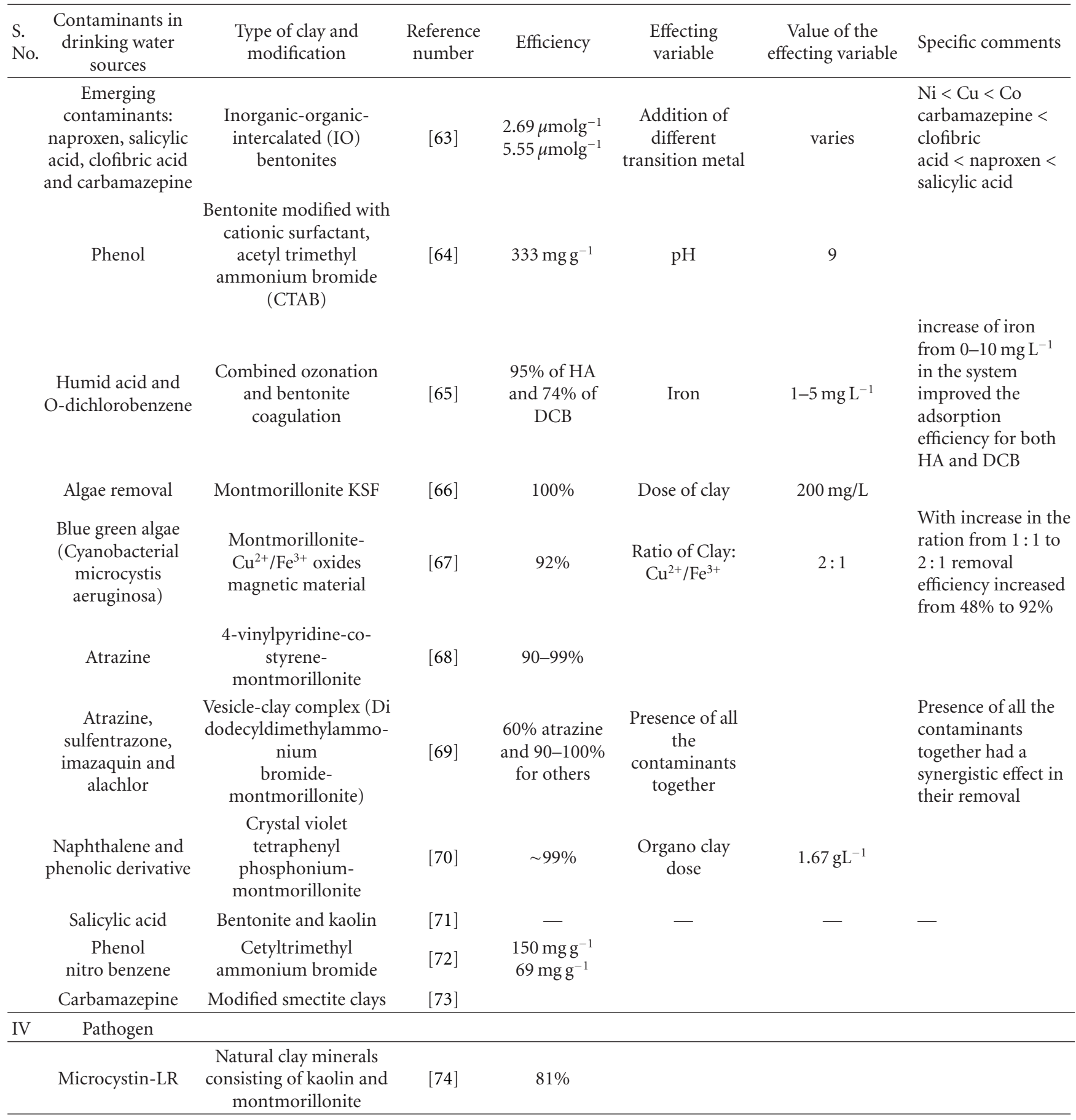

(1) Heavy Metals. Heavy metal contamination in drinking water resources has serious effects on the health of human beings, animals, and plants. Currently, many researchers are working in this field to find an appropriate solution for removing various metals present in the water. Application and efficiency of different type of natural clay and their composites in removing various metals like arsenic, iron, manganese, lead cadmium, uranium, chromium, selenium tungsten, and zinc are reviewed in the following sections. Clays and their modified forms have received wide attention recently for use as adsorbents of metal ions from aqueous medium because of their easy availability and comparatively less cost. [11].

Removal of heavy metals by natural clays and their modified forms, kaolinite and montmorillonite in particular, has been reviewed by Bhattacharyya and Sen Gupta [11]. Their review reports the modification of the above mentioned clays by pillaring with various polyoxy cations of $\mathrm{Zr}^{4+}, \mathrm{Al}^{3+}, \mathrm{Si}^{4+}$, $\mathrm{Ti}^{4+}, \mathrm{Fe}^{3+}, \mathrm{Cr}^{3+}$ or $\mathrm{Ga}^{3+}$, and so forth. The adsorption of toxic metals, namely, $\mathrm{As}, \mathrm{Cd}, \mathrm{Cr}, \mathrm{Co}, \mathrm{Cu}, \mathrm{Fe}, \mathrm{Pb}, \mathrm{Mn}, \mathrm{Ni}, \mathrm{Zn}$, and so forth, has been studied predominantly. They found 
montmorillonite and its modified forms have much higher metal adsorption capacity compared to that of kaolinite and its modified forms. Their work reports the successful and improved adsorption of metals like Cd $[26,27], \mathrm{Cr}[28], \mathrm{CO}$ $[29,30], \mathrm{Cu}[27,29,31,32] \mathrm{Fe}[33], \mathrm{Pb}[34,35], \mathrm{Mn}, \mathrm{Ni}$ $[29,32,36]$, and zinc $[31,37]$ by kaolinite, montmorillonite, and their modified forms. They found that montmorillonite and its modified forms have higher metal adsorbing capacity as compared to their counterparts.

Oliveira et al. [38] prepared clay iron oxide composite for adsorption of metal ions $\mathrm{Ni}^{2+}, \mathrm{Cu}^{2+}, \mathrm{Cd}^{2+}$, and $\mathrm{Zn}^{2+}$ from aqueous solution. They compared the metal adsorption capacity of bentonite clay and its magnetic composite. They showed that the presence of iron oxide increased the adsorption capacity of the bentonite. These adsorbents showed the advantage to be easily removed from the medium by a simple magnetic separation procedure after saturation is reached.

Beidellite, a low-cost and natural clay mineral, was used as an adsorbent for the removal of lead and cadmium ions from aqueous solutions in batch experiments by Etci et al. [39]. Beidellite used in this study was obtained from the Eastern Black Sea region in Turkey from small-sized deposits formed from the alteration of volcanic rocks. The X-ray diffractometer (XRD) analysis of the clay was performed. It was found to be beidellite clay mineral of the smectite group. Smectites are 2:1 phyllosilicates with a total negative layer charge. The formula of beidellite was found to be $\mathrm{Na} 0.5 \mathrm{Al}_{2}(\mathrm{Si}, \mathrm{Al})_{4} \mathrm{O}_{10}(\mathrm{OH})_{2} \cdot 2 \mathrm{H}_{2} \mathrm{O}$. The kinetics of adsorption process followed the pseudosecond-order reaction. The adsorption capacities $\left(\mathrm{Q}^{\circ}\right)$ of beidellite for lead and cadmium ions were calculated from the Langmuir isotherm. It was found that adsorption capacity was in the range of 83.3$86.9 \mathrm{mg} \mathrm{g}^{-1}$ for lead and $42-45.6 \mathrm{mg} \mathrm{g}^{-1}$ for cadmium at different temperatures. Thermodynamic studies showed that the metal uptake reaction by beidellite was endothermic in nature.

Natural montmorillonite clay coated with biopolymer chitosan was compared for its efficiency to remove tungsten from simulated drinking water in Neveda, USA, by Gecol et al. [40] Biopolymer-coated clay particles were synthesized. The effects of tungsten concentration in feed water (20$500 \mathrm{ppm})$ and water $\mathrm{pH}(4,5.5$ and 6.4) on the zeta potential of adsorbent particles, tungsten removal, and adsorption equilibrium were studied using chitosan-coated clay and natural clay. It was shown that coating clay particles with chitosan shifts the net surface charge of clay from negative to positive and the point of zero charge (PZC) of clay from 2.8 and 5.8. The net surface charge of biosorbent particles decreases with an increase in the tungsten concentration of feed water, because the positively charged sites are consumed by the adsorption of tungsten anions. Chitosan-coated clay was found to be much more effective than natural clay for the removal of tungsten. The tungsten removal efficiencies of both chitosan-coated clay and natural clay decrease with an increase in the $\mathrm{pH}$ level and an increase in the tungsten concentration of the feed water. Adsorption equilibrium studies show that tungsten removal is the highest at $\mathrm{pH}$ 4. Adsorption of tungsten species on both chitosan-coated clay and natural clay seemed to obey Langmuir isotherm within the range of concentrations and $\mathrm{pH}$ investigated. The maximum tungsten adsorption capacities of chitosan, chitosan coated clay and natural clay were found to be $632 \mathrm{mg}$ tungsten per gram of chitosan, $23.9 \mathrm{mg}$ tungsten per gram of chitosan coated clay, and $5.45 \mathrm{mg}$ tungsten per gram of natural clay at $\mathrm{pH} 4$, respectively. The tungsten species adsorption on chitosan coated clay was found to be effected by the ionic attraction between the protonated surface groups on chitosan and the negatively charged tungsten species. But, the tungsten species adsorption on natural clay is governed by the positively charged clay particle edges formed by broken bonds of $\mathrm{Al}-\mathrm{O}$ and $\mathrm{Si}-\mathrm{O}$.

Aytas et al. [41] investigated the effect of $\mathrm{pH}$, contact time, temperature, and initial metal concentration on uranium (U(VI)) adsorption on thermally activated bentonite (TAB). Graphical correlation of various adsorption isotherm models like Freundlich and Dubinin-Radushkevich were carried out for TAB. Various thermodynamic parameters such as Gibb's free energy, entropy, and enthalpy of the on-going adsorption process was calculated. Surface area, FT-IR, and DTA-TG spectra analyses were carried out to determine the adsorptive characteristic of bentonite sample. It was found that the adsorption properties of bentonites change when the samples are calcined at $350^{\circ}-550^{\circ} \mathrm{C}$, that is, at conditions that the layer structure is retained. When bentonite was calcinated at $400^{\circ} \mathrm{C}$, the adsorptive capacity is highest but decreases when above $400^{\circ} \mathrm{C}$. the reason being that the rise of temperature breaks the crystal structure and decreases the specific surface area and adsorbability. The TAB has a maximum sorption at $\mathrm{pH}$ 9.0. The initial $\mathrm{U}^{6+}$ concentration was varied from 25 to $125 \mathrm{mg} \mathrm{L}^{-1}$ to evaluate its effect on adsorption efficiency. The $\mathrm{U}^{6+}$ adsorption increased in the initial concentration range from 25 to $100 \mathrm{mg} \mathrm{L}^{-1}$ and slightly decreased after $100 \mathrm{mg} \mathrm{L}^{-1}$. The effect of contact time was studied using a constant concentration of uranium solution at $30^{\circ} \mathrm{C}$. The sorption of $\mathrm{U}^{6+}$ ions has been investigated in the contact time range of 5-180 minutes. It was shown that the variation of $K_{d}$ and percentage adsorption with shaking time for $\mathrm{U}^{6+}$ ions changes. It was determined that a higher removal percentage of uranium is obtained at the beginning of the adsorption. $K_{d}$ and percentage sorption of uranium at the optimum adsorption conditions were found as $196 \pm$ $6 \mathrm{~m} \mathrm{Lg}^{-1}$ and $66.2 \pm 0.7 \%$, respectively. The results show that TAB samples can be an alternative low-cost adsorbent for removing $\mathrm{U}^{6+}$ ions from aqueous solutions.

Mishra and Patel [42] studied the use of activated carbon, kaolin, bentonite, blast furnace slag, and fly ash as adsorbent with a particle size between 100 mesh and 200 mesh to remove the lead and zinc ions from water. The concentration of the solutions prepared was in the range of $50-100 \mathrm{mg} \mathrm{L}^{-1}$ for lead and zinc for single and binary systems which were diluted as required for batch experiments. The effect of contact time, $\mathrm{pH}$, and adsorbent dosage on the removal of lead and zinc by adsorption was investigated. The equilibrium time was found to be 30 minutes for activated carbon and 3 hours for kaolin, bentonite, blast furnace slag, and fly ash. The most effective $\mathrm{pH}$ value for lead and zinc removal was 6 for activated carbon. Variation in $\mathrm{pH}$ value did not affect lead and zinc removal significantly for other adsorbents. 
Adsorbent doses were varied from $5 \mathrm{gL}^{-1}$ to $20 \mathrm{gL}^{-1}$ for both lead and zinc solutions. An increase in adsorbent doses increased the percent removal of lead and zinc. A series of isotherm studies were undertaken and the data evaluated for compliance was found to match with the Langmuir and Freundlich isotherm models. To investigate the adsorption mechanism, the kinetic models were tested, and it follows second-order kinetics. Kinetic studies revealed that blast furnace slag was not effective for lead and zinc removal. From the results, it was found that bentonite and fly ash were effective for lead and zinc removal.

Batch tests were carried out by Yuan and his group [43] to investigate the removal mechanism of hexavalent chromium $\left[\mathrm{Cr}^{6+}\right]$ by montmorillonite-supported magnetite nanoparticles. Montmorillonite-supported magnetite nanoparticles were prepared by coprecipitation and hydrosol method [44]. The obtained materials were characterized by X-ray diffraction, nitrogen adsorption, elemental analysis, differential scanning calorimetry, transmission electron microscopy, and $\mathrm{X}$-ray photoelectron spectroscopy. The average sizes of the magnetite nanoparticles without and with montmorillonite support were found to be around 25 and $15 \mathrm{~nm}$, respectively. The montmorillonite-supported magnetite nanoparticles were present on the surface or inside the interparticle pores of clays, with better dispersing and less coaggregation than the ones without montmorillonite support. $\mathrm{The}^{\mathrm{Cr}}{ }^{6+}$ uptake were mainly governed by a physicochemical process, which included an electrostatic attraction followed by a redox process in which $\mathrm{Cr}^{6+}$ was reduced into trivalent chromium. The adsorption of $\mathrm{Cr}^{6+}$ was highly $\mathrm{pH}$ dependent, and the kinetics of the adsorption followed the pseudosecondorder model. The adsorption data of unsupported and clay-supported magnetite nanoparticles followed Langmuir and Freundlich isotherm models. The montmorillonitesupported magnetite nanoparticles showed a much better adsorption capacity per unit mass of magnetite $\left(15.3 \mathrm{mg} \mathrm{g}^{-1}\right)$ than unsupported magnetite $\left(10.6 \mathrm{mg} \mathrm{g}^{-1}\right)$ and were more thermally stable than their unsupported counterparts.

Cobalt adsorption efficiencies of kaolinite and montmorillonite was studied by Angove et al. [45] and Bhattacharyya and Sen Gupta [11]. Angove et al. [45] found the langmuir capacities as $1.5 \mathrm{mg} \mathrm{g}^{-1}$ at $313 \mathrm{k}$ and Bhattacharyya and Sen Gupta found it to $11.2 \mathrm{mg} \mathrm{g}^{-1}$ for kaolinite. For montmorillonite, Bhattacharyya and Sen Gupta found the Langmuir and freundilich values to be 28.6 and 4.6, respectively. Yavuz et al. [29] showed that adsorption of $\mathrm{Cu}^{2+}$ on kaolinite followed langmuir isotherm with adsorption capacity equal to $11.0 \mathrm{mg} \mathrm{g}^{-1}$.

Pandey and Mishra [16] prepared organic-inorganic composite of chitosan and nanoclay (Cloisite 10A) with combined properties of hydrophilicity of an organic polycation and adsorption capacity of inorganic polyanion. The chitosan/clay nanocomposite (CCN) was prepared by solvent casting method. The chemical, structural, and textural characteristics of the material were determined by FTIR, XRD, TEM, SEM, and EDAX analysis. XRD and TEM results indicated that an exfoliated structure was formed with addition of small amounts of MMT-Na ${ }^{+}$(montmorillonite$\mathrm{Na}^{+}$) to the chitosan matrix. These composite material were used for the removal of $\mathrm{Cr}^{6+}$ from aqueous solution. They showed that $\mathrm{pH} 3$ was found most suitable and adsorption data fits the Langmuir and Freundlich isotherms. The adsorption showed pseudosecond order kinetics with a rate constant of $8.0763 * 10^{-4} \mathrm{~g} \mathrm{mg}^{-1} \mathrm{~min}^{-1}$ at $100 \mathrm{ppm} \mathrm{Cr}^{6+}$ concentration.

The natural kaolin calcined at $550^{\circ} \mathrm{C}$ (mostly meta kaolin) and raw bentonite (mostly montmorillonite) pretreated with $\mathrm{Fe}^{2+}, \mathrm{Fe}^{3+}, \mathrm{Al}^{3+}$, and $\mathrm{Mn}^{2+}$ salts were used to remove As from the model anoxic groundwater with $\mathrm{As}^{3+}$ concentration about 0.5 and $10 \mathrm{mg} \mathrm{L}^{-1}$ by Doušová et al. [46]. The efficiency of $\mathrm{As}^{3+}$ sorption varied from $92 \%$ to $>99 \%$ by the sorption capacity higher than $4.5 \mathrm{mg} \mathrm{g}^{-1}$. In the case of metakaolin, $\mathrm{Fe}^{2+}$ and $\mathrm{Mn}^{2+}$ treatments proved the high sorption efficiency $>97 \%$ ), while only $<50 \%$ of As was removed after $\mathrm{Fe}^{2+}$ and $\mathrm{Al}^{3+}$ pretreatment. The sorption capacities of treated metakaolin ranged from 0.1 to $2.0 \mathrm{mg} \mathrm{g}^{-1}$. The utilization of low-grade clay materials as selective sorbents is one of the most effective possibilities of As removal from contaminated water reservoirs. It was shown that simple pretreatment of these materials with $\mathrm{Fe}(\mathrm{Al}$ and $\mathrm{Mn})$ salts significantly improved their sorption affinity to As oxyanions.

While many treatment technologies are available for arsenic removal from drinking water including coagulation/ filtration, lime softening, activated alumina adsorption, ion exchange, and membrane processes, most of these approaches are expensive and more suitable for large water systems. In this study, membranes made of low-cost clay minerals were explored by Fang et al. [47] for arsenate removal. Montmorillonite, kaolinite, and illite were selected for membrane preparation. Feed water spiked with arsenate was pumped through the compacted clay membranes and the effluent was collected at the lower pressure side for arsenic analysis. The ability of clay membranes to retain arsenic was investigated at different initial arsenic concentrations and ionic strengths controlled by sodium chloride. The influence of applied pressure and the permeate flux on arsenic removal efficiency was also examined. The results indicated that a greater than $90 \%$ of arsenic rejection could be achieved for water with $50-100 \mu \mathrm{g} \mathrm{L}^{-1}$ of arsenate using the clay membranes. It was observed that the required pressure for clay membrane filtration was significantly higher than that of synthetic organic membranes.

Water and wastewater studies in Malawi, South Africa, revealed very high levels of heavy metals in most streams and other water bodies particularly within their urban areas. The metals are produced and released during industrial and agricultural activities and also in vehicular emissions. The study conducted by Sajidu et al. [48] investigated the potential of mixed clay, obtained from the Tundulu area in removing $\mathrm{Cd}^{2+}, \mathrm{Cr}^{3+}, \mathrm{Cu}^{2+}, \mathrm{Hg}^{2+}, \mathrm{Pb}^{2+}$, and $\mathrm{Zn}^{2+}$ cations and $\mathrm{AsO}_{4}{ }^{3-}$ anions from aqueous solutions using batch equilibrium technique. Qualitative mineralogical characterization of the clay revealed that the clay contains illite, distorted kaolinite, mixed layer minerals, and nonclay mineral carbonate fluoroapatite. $\mathrm{pH}$ pzc for the raw clay, as determined by potentiometric titrations, was 9.66, while $\mathrm{pH}$ pzc of pretreated clay was 9.63. Pretreatment of the clay involved removal of carbonates, iron oxides, and organic matter. Initial 
total metal concentrations ranged from 3 to $5 \mathrm{mg} \mathrm{L}^{-1} \cdot \mathrm{pH}$ metal sorption dependence of the clay revealed $\mathrm{Cr}^{3+}$ removal from $\mathrm{pH}$ of 3 to complete removal at $\mathrm{pH} 5$ with over $90 \%$ of the removal attributable to adsorption on the clay while the remaining $10 \%$ attributable to both adsorption, and $\mathrm{Cr}(\mathrm{OH})_{3}$ precipitation. $\mathrm{Zn}^{2+}$ complete removal occurred at $\mathrm{pH}$ above 7 with $92 \%$ attributable to adsorption while the rest could be from both adsorption and hydroxide precipitation. $\mathrm{Cu}^{2+}$ was removed from $\mathrm{pH} 4$ and completely above $\mathrm{pH}$ 6.8 with $50 \%$ due to adsorption. $\mathrm{Cd}^{2+}$ removal was between $\mathrm{pH}$ of 6 and 9 with $85 \%$ due to adsorption to the clay. Lead was completely removed at $\mathrm{pH}$ greater than 7.67. Removal of $\mathrm{Hg}^{2+}$ at total $\mathrm{Hg}^{2+}$ concentration of $0.023 \mathrm{mM}$ was $\mathrm{pH}$ independent fluctuating between $30 \%$ and $60 \%$. No effective removal of $\mathrm{AsO}_{4}{ }^{3-}$ anion was observed.

Selenium is a natural trace element found in bedrock, but it is also introduced into the environment by anthropogenic activities, such as mining and combustion of fossil fuels [49, 50]. At low concentrations, selenium is an essential micronutrient for mammals, but consumption of quantities exceeding daily recommendations can cause health problems. Its toxicity [51] led the World Health Organization (WHO) and the European Union (EU) to recommend a maximum selenium concentration in drinking water of $10 \mathrm{ppb}$, while the Environment Protection Agency (EPA) sets a limit of $50 \mathrm{ppb}$.

Chitosan-montmorillonite composites were designed by Bleiman and Mishael [52] to adsorb selenium from water and its efficiency was compared with widely used commercial adsorbent aluminum oxide (Al-oxide) and feric oxide (Fe-oxide). The highest adsorption efficiency was obtained for chitosan-montmorillonite composites. These composites were characterized by XRD, zeta potential, and FTIR measurements. Adsorption isotherms of selenate on the composite, on Al-oxide, and on Fe-oxide were in good agreement with the Langmuir model, yielding a somewhat higher capacity for the composite, $18.4,17.2$, and $8.2 \mathrm{mgg}^{-1}$, respectively. In addition, adsorption by the composite was not $\mathrm{pH}$ dependent, while its adsorption by the oxides decreased at higher $\mathrm{pH}$. Selenium removal from well water (closed due to high selenium concentrations, $0.1 \mathrm{mg} \mathrm{L}^{-1}$ ) by the composite, brought levels to below the WHO limit $\left(0.01 \mathrm{mgL}^{-1}\right)$ and was selective for selenium even in the presence of sulfur $\left(13 \mathrm{mg} \mathrm{L}^{-1}\right)$. Selenium adsorption by the composite was higher than by the Al-oxide due to high adsorption of sulfur by the latter. It was found that the polymer clay composite is an innovative sorbent that in suspension efficiently removed selenium from well water with high selenium concentrations. On the other hand, the Al-oxide efficiently removed selenium from the well water when employed in filtration columns.

$\mathrm{Na}$ et al. [53] investigated the adsorption of arsenate and arsenite from aqueous solutions using Ti-pillared montmorillonite (Ti-MMT) as a function of contact time, $\mathrm{pH}$, temperature, coexisting ions, and ionic strength. The adsorption of both arsenate and arsenite were temperature and $\mathrm{pH}$ dependent, indicating different adsorption mechanisms. The effect of coexisting ions on the adsorption was also studied, and, among the ions investigated, only phosphate had a noticeable influence on the adsorption of arsenate, while the effect of other ions was negligible. A pseudosecond-order chemical reaction model was obtained for both arsenate and arsenite; adsorption isotherms of arsenate and arsenite fitted the Langmuir and Freundlich isotherm models well. Xray diffraction (XRD) and X-ray photoelectron spectroscopy (XPS) were used to study the nature of surface elements before and after adsorption. This work demonstrates that Ti-pillared montmorillonite is an efficient material for the removal of arsenate and arsenite from aqueous solutions. It was found that the removal capacity of arsenite decreased with increase in temperature, whereas the adsorption of arsenate shows the same trend in the temperature range $25^{\circ} \mathrm{C}-$ $35^{\circ} \mathrm{C}$ but an inverse trend between $45^{\circ} \mathrm{C}$ and $65^{\circ} \mathrm{C}$. To test the effect of coexisting anions (phosphate, nitrate, and sulfate) present in natural water on arsenite and arsenate removal, simulated water experiments were performed. Experimental results showed that none of these three anions had any noticeable influence on the adsorption of arsenite, while the presence of phosphate significantly decreased the adsorption capacity of arsenate. The reason for decrease in absorption efficiency of $\mathrm{As}^{5+}$ in the presence of phosphate was explained as competition between phosphate and arsenate ions on limited availability of adsorption sites.

Ake et al. [54] prepared a binary clay composite for adsorption of lead from the contaminated water. They prepared clay-carboxy methyl cellulose composite. The binary composite had higher efficiency for adsorption of lead from solution, while providing void volume, increased surface area, and considerably enhanced hydraulic conductivity. The results suggested that a combination of sodium montmorillonite clay and carbon exhibited enhanced sorption of lead compared to carbon alone and also supported the potential application of various combinations of sorbent materials.

Zhao et al. [55] prepared clay composite by embedding bentonite in polyacrylamide (PAAm) gels for adsorption of $\mathrm{Cu}^{2+}$ ions from the ground and surface waters. These composite materials combine the elasticity and permeability of gels with the high ability of clays to adsorb heavy metal ions. The sorption and desorption of $\mathrm{Cu}^{2+}$ on bentonite-polyacrylamide (BENT-PAAm) was investigated by Zhao group as the function of $\mathrm{pH}$, ionic strength, adsorbent content, $\mathrm{Cu}$ (II) concentrations, and temperature. The results indicated that the sorption of $\mathrm{Cu}^{2+}$ on BENT-PAAm was strongly dependent on $\mathrm{pH}$, ionic strength, and temperature. The sorption increased from about $9 \%$ to $97 \%$ at $\mathrm{pH}$ ranging from 2.4 to 7 . The sorption of $\mathrm{Cu}^{2+}$ on BENT-PAAm increased with increasing temperature and decreasing ionic strength. The sorption of $\mathrm{Cu}^{2+}$ on BENT and on BENTPAAm was reported as endothermic and irreversible process.

A superabsorbent composite (SAC) was synthesized by copolymerization reaction of partially neutralized acrylic acid (AA) on bentonite micropowder using N, N_-methylenebisacrylamide as a crosslinker and ammonium persulfate as an initiator in aqueous solution by Bulut et al. [56] using solution polymerization technique. The water absorbency of synthesized SAC was reported as 352 and $110 \mathrm{~g} \mathrm{H}_{2} \mathrm{Og}^{-1}$ in distilled water and $0.2 \% \mathrm{NaCl}$, respectively. Sorption capacity of SAC was investigated for heavy metal ions (HMI) using Langmuir and Freundlich model of adsorption. 
The maximum adsorption capacity of HMI onto the bentonite-based SAC from their solution was found to be 1666.67, 270.27, 416.67, and $222.22 \mathrm{mg} \mathrm{g}^{-1}$ for $\mathrm{Pb}^{2+}, \mathrm{Ni}^{2+}, \mathrm{Cd}^{2+}$, and $\mathrm{Cu}^{2+}$, respectively.

(2) Inorganic Contaminant. Inorganic contamination of drinking water and its sources is caused by natural and anthropogenic factors. Fluorosis is endemic in at least 25 countries across the globe and has affected millions of people [75-77]. It is caused by high concentration of fluoride above $1.5 \mathrm{mg} \mathrm{L}^{-1}$ in drinking water [78]. Fluoride is beneficial when present within the permissible limit of $1.0-1.5 \mathrm{mg} \mathrm{L}^{-1}$ for calcification of dental enamels [79]. Similarly, excess of nitrates in drinking water causes methemoglobinemia or blue baby disease. Thus, management of these inorganic contaminants in water is of prime importance.

Low-cost bentonite clay was chemically modified using magnesium chloride in order to enhance its fluoride removal capacity by Thakre et al. [57]. The magnesium incorporated bentonite $(\mathrm{MB})$ was characterized by using XRD and SEM techniques. Batch adsorption experiments were conducted to study and optimize various operational parameters such as adsorbent dose, contact time, $\mathrm{pH}$, effect of coions, and initial fluoride concentration. It was observed that the $\mathrm{MB}$ works effectively over wide range of $\mathrm{pH}$ and showed a maximum fluoride removal capacity of $2.26 \mathrm{mg} \mathrm{g}^{-1}$ at an initial fluoride concentration of $5 \mathrm{mg} \mathrm{L}^{-1}$, which is much better than the unmodified bentonite. The experimental data fit well into Langmuir adsorption isotherm and followed pseudofirst-order kinetics. Thermodynamic study suggested that fluoride adsorption on $\mathrm{MB}$ is reasonably spontaneous and an endothermic process. MB showed significantly high fluoride removal in synthetic water as compared to field water. Desorption study of MB suggested that almost all the loaded fluoride was desorbed ( $97 \%)$ using $1 \mathrm{M} \mathrm{NaOH}$ solution; however, maximum fluoride removal decreased from 95.47 to 73 (\%) after regeneration. From the experimental results, it was inferred that chemical modification enhances the fluoride removal efficiency of bentonite and it works as an effective adsorbent for defluoridation of water.

Adsorption potential of metal oxide (lanthanum (La), magnesium $(\mathrm{Mg})$, and manganese $(\mathrm{Mn})$ ) incorporated bentonite clay was investigated by Kamble et al. [58] for defluoridation of drinking water using batch equilibrium experiments to gain insight of adsorption behavior, kinetics, and mechanisms of adsorption of fluoride ion. The effect of various physicochemical parameters such as $\mathrm{pH}$, adsorbent dose, initial fluoride concentration, and the presence of interfering coions on adsorption of fluoride has been investigated. The $10 \%$ La-bentonite showed higher fluoride uptake capacity for defluoridation of drinking water as compared to Mg-bentonite, Mn-bentonite, and bare bentonite clay. The uptake of fluoride in acidic $\mathrm{pH}$ was higher as compared to alkaline $\mathrm{pH}$. The equilibrium adsorption data fitted reasonably well in both Langmuir and Freundlich isotherm models. It was also observed that the presence of certain coexisting ions can have positive effect on removal of fluoride, while carbonate and bicarbonate anions showed deleterious effect. The rate of adsorption was reasonably rapid, and maximum fluoride uptake was attained within 30 minutes. The modified adsorbent material showed better fluoride removal properties for actual field water, which could be due to the positive effect of other coions present in the field water.

Defluoridation from aqueous solutions by zirconium(Zr) loaded bentonite (ZLB) was studied by Ma et al. [59]. It has been found that maximum adsorption of fluoride from aqueous solutions takes place below $\mathrm{pH}$ 6. The fluoride adsorption followed the mechanism of ion exchange.

Groundwater pollution by nitrates is a widespread problem in many locations in the world. The underground aquatic mantle of the Peninsula of Yucatan, Mexico, is highly vulnerable due to its karstic nature. Adsorption methods are a good choice for nitrate elimination. In this work, MenaDuran et al. [60] modified natural calcium bentonite by acid thermoactivation using $\mathrm{HCl}$ and $\mathrm{H}_{2} \mathrm{SO}_{4}$, and tested it as a media for nitrate removal in an aqueous solution. Acid thermoactivation is a process that allows the controlled extraction of aluminum ions from the crystalline structure of the clay, also introducing an acceptable acidity level. This process modifies the textural properties of clays favoring a greater porosity and surface area. The nitrate concentration in the solution was measured by FT-IR, using the Lambert-Beer law. Clay characterization was carried out by X-ray diffraction and FT-IR spectroscopy; surface area was measured by the BET method. It was shown by Mena-Duran and group that natural clays modified by acid thermoactivation are capable of nitrate removal in aqueous solutions. Nitrate adsorption was found to be proportional to the stirring time. Calcium montmorillonite activated by hydrochloric acid showed a better nitrate removal capacity, up to $22.28 \%$ when the stirring time was increased from 0.5 hours to 68 hours. The ionic exchange was confirmed by the presence of $\mathrm{KCl}$ in the clay residue. The BET area measurements showed no direct relation between the surface area and the nitrate removal capacity. Infrared spectroscopy was used to measure the nitrates adsorbed by the natural clay materials.

(3) Organic Contaminants. Clays offer an attractive and inexpensive option for the removal of organic and inorganic contaminants [80]. The adsorption of several organic contaminants in water such as pesticides, phenols, and chlorophenols has been reported recently in the literature [81-87].

Chloroacetic acids, such as trichloroacetic acid (TCAA), dichloroacetic acid (DCAA), and monochloroacetic acid (MCAA) are receiving increasing attention in the literature [88]. These chloroacetic acids, commonly formed during the reactions between chlorine and natural organic matter $(\mathrm{NOM})$ during prechlorination or disinfection in potable water production, have been shown to be carcinogenic and may potentially pose a risk to human health [89].

Chloroacetic acids, formed during the disinfection process in potable water production, are considered to pose a potential risk to human health. In this work, $\mathrm{Gu}$ et al. [61] investigated dichloroacetic acid (DCAA) removal from drinking water by using a process of bentonite-based adsorptive ozonation. This process is formed by combined addition 
of ozone, bentonite, and $\mathrm{Fe}^{3+}$. During the reaction, DCAA is removed by the joint effect of adsorption, ozonation, and catalytic oxidation. In addition, under the effect of the adsorption, natural organic matters (NOM) can be adsorbed onto the bentonite surface, resulting in a reduced scavenging effect toward $\mathrm{HO} \cdot$ radicals, and hence eliminate the negative effect of NOM on DCAA removal. It was explained that at the initial stage of the reaction, $\mathrm{Fe}^{3+}$ is rapidly hydrolyzed to polycations and adsorbed onto the bentonite surface or into its structural layers. This charges the surface of the bentonite with positive ions, which, in turn, increases its surface area, resulting in a strong adsorption of HA or DCAA. Furthermore, $\mathrm{Fe}^{3+}$ catalyzes ozone decomposition to form $\mathrm{HO}$, thus further improving the efficiency. Experimental results show that ozonation alone removes $40 \%$, bentonite (dosage $100 \mathrm{mg} \mathrm{L}^{-1}$ ) enhanced ozonation removes $51 \%$, and addition of $\mathrm{Fe}^{3+}$ increases the DCAA removal by $68 \%$. It was observed that increasing the dose of $\mathrm{Fe}^{3+}$ from $0.5-5 \mathrm{mg} \mathrm{L}^{-1}$, DCAA removal increases significantly to $92 \%$. The optimum time was found to be 40 minutes. The adsorptive ozonation has been shown to be potentially advantageous in destruction of toxic, dissolved pollutants in drinking water and appears to have great potential for a wide range of treatment applications.

In another study by Lu and Pan [62], the adsorption method using quaternary ammonium salt modified bentonite as the adsorbent was used for the removal of carbon tetrachloride (CT) in simulated groundwater sample. The morphology of bentonite before and after modification was observed through scanning electron microscope (SEM). The effects of bentonite dosage, adsorption time, and temperature on removal rate of CT were investigated. The SEM results showed that after natural calcium-bentonite is modified by quaternary ammonium salt, the particle clearance of the modified bentonite obviously increased, and the surface property changed from originally hydrophilic to hydrophobic, enabling it to effectively adsorb and remove CT from water. The optimal adsorption conditions obtained were bentonite dosage $5.0 \mathrm{gL}^{-1}$, adsorption time 2 hours, and temperature $30^{\circ} \mathrm{C}$. Under these optimized conditions, the removal efficiency of CT reached above $70 \%$ when modified bentonite was used in treating actual groundwater polluted by CT.

Rivera-Jimanez [63] modified inorganic-organic-intercalated (IO) bentonites with $\mathrm{Co}^{2+}, \mathrm{Ni}^{2+}$, or $\mathrm{Cu}^{2+}$ and created adsorbents for the removal of relevant emerging contaminants (naproxen, salicylic acid, clofibric acid, and carbamazepine) from water to overcome challenges associated with low concentration and polar nature of these contaminants. Characterization of the materials using X-ray diffraction, porosimetry, scanning electron microscopy, thermal gravimetric analysis, and Fourier transform infrared spectroscopy indicated general structural integrity. It was found that the metal loading increased in the following order: $\mathrm{Ni}<\mathrm{Cu}<\mathrm{Co}$. Single-point adsorption experiments were done at room temperature with different $\mathrm{pH}$ conditions and using initial adsorbate concentration of $14 \mathrm{ppm}$. In general, the transition metal-modified IO bentonites displayed adsorption capacities that varied depending on the type of metal, $\mathrm{pH}$, and nature of the adsorbate. The largest adsorption capacity was observed for salicylic acid, with removal of $5.5 \mu \mathrm{molg}^{-1}$ using $\mathrm{Cu}^{2+}$ modified hexadecyltrimethylammonium bromide (HDTMAB, $\geq 99.0 \%$ purity) natural bentonites. According to Rivera-Jimenez, the behavior could have been because of its smaller footprint. The higher $\mathrm{pH}$ was found to be the optimum for maximum removal efficiency. From the results, it was concluded that the presence of some functional groups plays an important role during the adsorption of a particular adsorbate, possibly indicating complexation with the transition metal. For carbamazepine, although the observed adsorption loadings were comparable to those of other adsorbents, the modification of the IO bentonites does not appear to enhance the unmodified material capacity. This could have been because of the absence of key functional groups in this particular adsorbate.

A natural bentonite modified with a cationic surfactant, acetyl trimethylammonium bromide (CTAB), was used as an adsorbent for removal of phenol from aqueous solutions by Senturk et al. [64]. The natural and modified bentonites (organobentonite) were characterized by FTIR, XRD, and SEM. Batch adsorption experiments were performed to study the effects of various parameters such as solution $\mathrm{pH}$, contact time, initial phenol concentration, organobentonite concentration, and temperature on phenol adsorption onto organobentonite. Maximum phenol removal was observed at pH 9.0. Equilibrium was attained after contact of one hour only. At equilibrium, the organobentonite concentration was $10 \mathrm{gL}^{-1}$ with initial phenol concentration of $100 \mathrm{mg} \mathrm{L}^{-1}$. The adsorption isotherms were described by Langmuir and Freundlich isotherm models, and both models fit well. The monolayer adsorption capacity of organobentonite was found to be $333 \mathrm{mg} \mathrm{g}^{-1}$.

Combined ozonation and bentonite coagulation process (COBC) was investigated by $\mathrm{Gu}$ et al. [65] as a method of concurrently removing humic acid (HA) and o-dichlorobenzene (DCB) from drinking water. When compared with only ozonation and coagulation, $\mathrm{COBC}$ was highly efficient in removing the $\mathrm{HA}$ and $\mathrm{DCB}$ concurrently. In this study, it was shown that in this process, HA and DCB were removed by joint effect of catalytic ozonation and bentonite coagulation. HA removal was highly dependent on the coagulation process, while DCB removal was dependent on the oxidation process in COBC. Iron in solution not only acted as a coagulant, but also promoted the formation of $\mathrm{HO}$., which is effective in destroying aromatic chemicals. Bentonite in COBC improved the coagulation process, resulting in enhancement in the treating efficiency. COBC has proved to be potentially advantageous on dissolved pollutants in drinking water and appears to have great potential for a wide range of practical applications.

Algae are most common aquatic species which grow and inhabit sea, lakes, and rivers. Very rapid growth of algae can, therefore, cause problems in the water supply industry, such as water discoloration, taste, odor, and blockage of filters. In particular, some types of algae (e.g., blue-green algae) can be toxic to humans and other organisms. If an excessive growth of algae occurs, endogeneous toxins (e.g., microcystin and nodularin) emitted act as hepatoxins, while anatoxin and saxitoxin act as neurotoxins; these may cause serious damage 
to both humans and animals alike $[90,91]$. Therefore, the blooming of algae not only worsens water treatment performance and then deteriorates water quality, but also results in the toxic effect on human beings and animals.

In this study, Jiang and Kim [66] compared the algae removal efficiency of clay composites with widely used commercial metal coagulants in simulated water. The coagulants used in this study included aluminium sulphate (AS) and polyaluminium chloride (PACl). AS had the Al content of $8 \%$ $\mathrm{w} / \mathrm{w}$ as $\mathrm{Al}_{2} \mathrm{O}_{3}$ and PACl (PAX-XL9) had the $\mathrm{Al}$ content of $8.5 \% \mathrm{w} / \mathrm{w}$ as $\mathrm{Al}_{2} \mathrm{O}_{3}$, with the basicity of 53.8 , and four clays, bentonite (Bent), sodium modified bentonite (Na-Bent), montmorillonite KSF (Mont-KSF), and montmorillonite K10 (Mont-K10). A standard jar test procedure [92] was applied to assess the coagulation performance. The shape of algae-clay flocs was examined by a scanning electron microscope (SEM). Experimental results show that coagulation with both metal coagulants and clays effectively removed algal cells from water. Prepolymerized inorganic coagulants (e.g., polyaluminium chloride, $\mathrm{PACl}$ ) normally contain high positive charge so algal removal occurs by charge neutralization mechanism. This results in better performance of $\mathrm{PACl}$ in the removal of algae. In comparison with aluminium sulphate (AS), polyaluminium chloride $(\mathrm{PACl})$ achieved a better performance with respect to algal removal. Excellent algal removal efficiency of the clays Bent and Mont-KSF was observed. For a dose of $200 \mathrm{mg} / \mathrm{L}$, the percentage removal of chlorophyll-a achieved by both clays was $100 \%$, which is greater than the efficiency of $\mathrm{PACl}$, for all the dose ranges investigated. In turbidity reduction experiments, Bent did not perform as well as Mont-KSF. The doses clay and PACl for removal of algae was found to be $200 \mathrm{mg} \mathrm{L}^{-1}$ and $1.5 \mathrm{mg} \mathrm{L}^{-1}$, respectively. Abundant availability, low cost, together with nonharmful chemical residuals in the treated water by clays make it a very efficient alternative treatment reagent in coping with the problems of algae.

In another study by Gao et al. [67], montmorillonite$\mathrm{Cu}(\mathrm{II}) / \mathrm{Fe}(\mathrm{III})$ oxides magnetic material was prepared and used for removal of harmful algae from water. The material was prepared by the support of $\mathrm{Cu}^{2+} / \mathrm{Fe}^{3+}$ oxides on pillared montmorillonite and was characterized by XRD, zeta potential measurements. The prepared magnetic material was effective for the removal of cyanobacterial Microcystis aeruginosa, and the loaded particles were chemically regenerated using acetone solution. The removal increased with the decrease in $\mathrm{pH}$ and the increase of ionic strength and $\mathrm{Ca}^{2+}$ concentration.

Atrazine(2-chloro-4-ethylamino-6-isopropylamino-striazine) is currently one of the most widely applied herbicides in the US [93]. It has been detected at high concentrations in ground and surface waters all over Europe and North America [94-97] due to its extensive use, ability to persist in soils, low sediment partitioning, slow rate of degradation, and its tendency to travel with water. In the US, the upper limit for atrazine in drinking water is $3 \mathrm{ppb}$, whereas the European Union legislation banned its use (since 2003) and fixed a limit of $0.1 \mathrm{ppb}$ [98]. Several methods and technology had been used to remove atrazine from contaminated water. But all of them proved to very expensive.
A number of studies explored modifying silicate minerals (clays and zeolites) as adsorbents for atrazine. Lemić et al. [99] examined removal of atrazine, lindane, and diazinon from water by organozeolites. However, the adsorption capacity for atrazine was the lowest $\left(2.0 \mathrm{mmolg}^{-1}\right)$. SanchezMartin et al. [100] employed clay minerals modified by a cationic surfactant in batch and column experiments for the adsorption of pesticides. The results showed an increase in the adsorption ability compared to untreated clays, but the adsorption coefficient of atrazine was very low. Borisover et al. [101] reached high sorption values of atrazine ( $98 \%$ after $18 \mathrm{~h}$ ) on dye-clay complexes; however, the adsorbent concentration was very high $\left(50 \mathrm{gL}^{-1}\right)$. Modification of the clay minerals vermiculite and montmorillonite by intercalating $\mathrm{Fe}(\mathrm{III})$ polymers for the removal of atrazine and its metabolites was examined [102]. Enhancement in the adsorption capacity was observed for both intercalated clays in comparison with the potassium clays although the adsorption time was relatively high $(24 \mathrm{~h})$.

The studies described above did not include the effect of dissolved organic matter (DOM) or a comparison to granular activated carbon (GAC). Streat and Sweetland [103] compared the adsorption of atrazine by hypersol-macronet polymer phases and by GAC F-400 and found that the GAC was more effective for the removal of atrazine than the polymer phases. Only a few studies focused on applying polymerclay composites as sorbents for organic pollutants [104, 105]. The study of Churchman [104] on the formation of polycation-clay composites and their use as sorbents for nonionic and anionic pollutants. Breen [105] examined the use of polycation-exchanged clays as sorbents for organic pollutants and studied the influence of layer charge on pollutant sorption capacity. Radian and Mishael [106] studied the binding of an herbicide to polycation-clay composites for the design of controlled release herbicide formulations.

Zadaka et al. [68] studied the effect of DOM on atrazine removal by the polymer-clay composite and by GAC. The removal of atrazine (2-chloro-4-ethylamino-6-isopropylamino-s-triazine), a widely used herbicide, removal from water by two polycations preadsorbed on montmorillonite was studied. Batch experiments demonstrated that the most suitable composite poly (4-vinylpyridine-co-styrene)montmorillonite (PVP-co-S-90\%-mont.) removed 90-99\% of atrazine $(0.5-28 \mathrm{ppm})$ within $20-40 \mathrm{~min}$ at $0.367 \% \mathrm{w} / \mathrm{w}$. Calculations employing Langmuir's equation could simulate and predict the kinetics and final extents of atrazine adsorption. Columns filter experiments (columns $20 \times 1.6 \mathrm{~cm}$ ) which included $2 \mathrm{~g}$ of the PVP-co-S-90\%-mont. composite mixed with excess sand removed $93 \%-96 \%$ of atrazine $(800 \mathrm{ppb})$ for the first 800 pore volumes, whereas the same amount of granular activated carbon (GAC) removed $83 \%-$ $75 \%$. In the presence of dissolved organic matter (DOM; $3.7 \mathrm{ppm}$ ), the efficiency of the GAC filter to remove atrazine decreased significantly $(68 \%-52 \%$ removal), whereas the corresponding efficiency of the PVP-co-S-90\%-mont. filter was only slightly influenced by DOM. At lower atrazine concentration (7 ppb), the PVP-co-S-90\%-mont. filter reduced even after 3000 pore volumes the emerging atrazine concentration below $3 \mathrm{ppb}$ (USEPA standard). In the case of 
the GAC filter, the emerging atrazine concentration was between 2.4 and $5.3 \mu \mathrm{gL}^{-1}$ even for the first 100 pore volumes. From the above experimental results, the PVP-coS-90\%-mont. composite can be used as an efficient material for the removal of atrazine from water.

This study by Undabeytia et al. [69] presents the vesicleclay complex as a powerful sorbing material for water purification of organic contaminants by both filtration and sedimentation. A main advantage of the vesicle-clay system stems from providing a relatively large number of highly hydrophobic sites, which yields efficient and large capacity of adsorption for neutral and anionic pollutants. Vesicle-clay complexes in which positively charged vesicles composed of didodecyldimethylammonium bromide (DDAB) were adsorbed on montmorillonite removed efficiently anionic (sulfentrazone and imazaquin) and neutral (alachlor and atrazine) pollutants from water. These complexes $(0.5 \% \mathrm{w}: \mathrm{w})$ removed $92 \%-100 \%$ of sulfentrazone, imazaquin, and alachlor and $60 \%$ of atrazine from a solution containing $10 \mathrm{mgL}^{-1}$ of it. A synergistic effect on the adsorption of atrazine was observed when all pollutants were present simultaneously $\left(30 \mathrm{mg} \mathrm{L}^{-1}\right.$ each), its percentage of removal being 85.5 percent. Column filters $(18 \mathrm{~cm})$ filled with a mixture of quartz sand and vesicle-clay $(100: 1, w: w)$ were tested. For the passage of one liter (25 pore volumes) of a solution including all the pollutants at $10 \mathrm{mg} \mathrm{L}^{-1}$ each, removal was complete for sulfentrazone and imazaquin, 94\% for alachlor, and 53.1\% for atrazine, whereas removal was significantly less efficient when using activated carbon.

The research by Rytwo et al. [70] show the efficient sorption of naphthalene and several phenolic derivatives to organoclays prepared by adsorption of crystal violet or tetraphenylphosphonium ions on montmorillonite until a charged-neutralized surface is obtained. The amounts of pollutant adsorbed are at least of the same order of magnitude as those measured for high-quality activated carbon, but the adsorption proceeds almost immediately, whereas for activated carbon it takes longer. The proposed organoclays were mixed with sand and tested in column filters, showing complete removal of high concentration of pollutant at several pore volumes. The adsorbents can also efficiently be applied in sequential batch reactors due to the fast adsorption kinetic, followed by flocculation that allows easy separation of the purified effluent. A volume of $150 \mathrm{~mL}$ of a $1000 \mu \mathrm{M}$ TCP solution was completely purified to levels below $3 \mu \mathrm{M}$, by means of $0.25 \mathrm{~g}$ organoclay.

The work by Bonina et al. [71] described the interactions between two commercial clays, bentonite and kaolin, and an iron-salicylate complex on the removal efficiency of salicylic acid. Adsorption experiments were accomplished using a water solution containing $\mathrm{Fe}^{3+} 0.0176 \mathrm{M}$ and salicylic acid 0.0253 M. Natural and treated clay samples were characterized by chemical analyses, powder X-ray diffraction and thermal analyses. It was shown that time dependence of salicylic acid adsorption by bentonite followed first-order kinetics, with respect to the percentage of salicylic acid adsorbed, in the first twelve hours; afterwards, the reaction slowed down. The reaction is completely exhausted after 2 days, and during the next 4 days, the concentration of salicylic acid in bentonite does not change from its asymptotic value of $8.0 \%$. The adsorption kinetics of salicylic acid by kaolin showed a slow adsorption beginning after the fourth day of treatment and finished after 19 days. The amount of salicylic acid adsorbed was $5.5 \%$ of the final complex. The release of salicylic acid adsorbed by bentonite and kaolin was tested in $0.2 \mathrm{~N}$ solutions of $\mathrm{Na}^{+}, \mathrm{K}^{+}, \mathrm{Mg}^{2+}$, and $\mathrm{Ca}^{2+}$. Salicylic acid release rates from $\mathrm{Fe}$ (III)-salicylate-containing bentonite were also measured through cellulose acetate membranes by means of Franz-type diffusion cells: an initial slow release of salicylic acid was followed by a fast release phase; after 23 hours, the concentration of salicylic acid released can be considered constant and the drug desorbed was $1.4 \%$ of the amount adsorbed by the bentonite. Even if the desorbed amount of salicylic acid is not very high, the bentonite-salicylate complex could be suitable for an application by gradual release.

Wang et al. [107] prepared a series of cetyltrimethyl ammonium bromide bentonite $(\mathrm{C}-\mathrm{Bt})$, cationic polyacrylamide bentonite (P-Bt), and composite organobentonite (C/P-Bt) by modifying bentonite with cetyltrimethyl ammonium bromide (CTMAB) and/or cationic polyacrylamide (CPAM). They measured the basal spacings of the synthesized organobentonites using XRD. The sorption capacities of phenol and nitrobenzene to these organobentonites from water were examined. The results showed that the basal spacing values of $\mathrm{C} / \mathrm{P}-\mathrm{Bt}$ were larger than those of $\mathrm{C}-\mathrm{Bt}$ and $\mathrm{P}-\mathrm{Bt}$, which indicated a simultaneous intercalation of bentonite interlayers by CTMAB and CPAM. The sorption capacity of C/P-Bt was better than that of C-Bt. Under the same equilibrium concentration $\left(7045 \mathrm{mg} \mathrm{L}^{-1}\right.$ for phenol and $409 \mathrm{mg} \mathrm{L}^{-1}$ for nitrobenzene), the sorbed amounts of phenol and nitrobenzene on $60 \mathrm{C} / 4 \% \mathrm{P}-\mathrm{Bt}$ were 150 and $69 \mathrm{mg} \mathrm{g}^{-1}$, which enhanced $26 \%$ and $28 \%$, respectively, comparing with those on $60 \mathrm{C}-\mathrm{Bt}$. There was an improved adsorption efficiency because of the arrangement model of CTMAB within the C/P-Bt interlayers was affected by CPAM, which led to the formation of organic phase with better affinity to the organic compounds.

Carbamazepine is a prescription anticonvulsant and mood stabilizing pharmaceutical administered to humans. Carbamazepine is persistent in the environment and frequently detected in water systems. Sorption and desorption of carbamazepine from water was measured for smectite clays with the surface negative charges compensated with $\mathrm{K}^{+}, \mathrm{Ca}^{2+}, \mathrm{NH}_{4}{ }^{+}$, tetramethylammonium (TMA), trimethylphenylammonium (TMPA), and hexadecyltrimethylammonium (HDTMA) cations by Zhang et al. [73]. Sorption of carbamazepine by TMPA and HDTMA smectites from water was found to be 10-150 times greater than sorption by $\mathrm{K}-$, $\mathrm{Ca}-$, and TMA-smectites within the measured aqueous carbamazepine concentrations $\left(0.1-1.0 \mathrm{mg} \mathrm{L}^{-1}\right)$. As per the experimental results, the magnitude of sorption followed the order: TMPA-smectite $\geq$ HDTMA-smectite > NH4-smectite $>$ K-smectite $>$ Ca-smectite $\geq$ TMA-smectite. The greatest sorption of carbamazepine by TMPA-smectite is attributed to the interaction of conjugate aromatic moiety in carbamazepine with the phenyl ring in TMPA through $\pi-\pi$ interaction. Partitioning process is the primary mechanism 
for carbamazepine uptake by HDTMA smectite. For $\mathrm{NH}_{4}$ smectite, the urea moiety in carbamazepine interacts with exchanged cation $\mathrm{NH}_{4}{ }^{+}$by $\mathrm{H}$-bonding, hence demonstrating relatively higher adsorption. Sorption by K-, Ca-, and TMAsmectites from water occurs on aluminosilicate mineral surfaces [73].

(4) Pathogens. The microcystins are potent mammalian liver toxins [107], known to be potent and specific in vitro inhibitors of the catalytic subunits of protein phosphatases-1 and $2 \mathrm{~A}[108,109]$ and are extremely potent tumor promoters $[110,111]$. Since it is widely suspected that many conventional water treatment methods are ineffective at reducing human exposure to microcystins, investigations into economic and practical methods of remedial water treatment are important. Although removal of cyanobacterial cells and toxins from drinking water using domestic water filters resulted in marginal success [112], it is following the termination of cyanobacterial growth that the majority of microcystins are considered to enter into the surrounding water after lysis and cell death. To date, perhaps photoirradiation is the most promising new method for detoxifying microcystins in raw water [113-115]. In a recent report Harada and Tsuji [116] looked at the persistence and decomposition of these hepatotoxins in the natural environment. Five pathways were considered as contributing to natural routes of detoxification. Of relevance to the work presented here is that it was ascertained that microcystins are absorbed strongly on sediment and that they are difficult to recover. The results of microcystin-LR scavenged by naturally occurring clay minerals are reported by Harada and Tsuji. The microcystin cyanobacterial hepatotoxins represent an increasingly severe global health hazard. Since microcystins are found worldwide in drinking water reservoirs concern about the impact on human health has prompted investigations into remedial water treatment methods. The preliminary study by Morris et al. [74] investigated the scavenging from water of microcystin-LR by fine-grained particles known to have a high concentration of the clay minerals kaolinite and montmorillonite. The results show that more than $81 \%$ of microcystin-LR can be removed from water by clay material. Thus, microcystin-LR is indeed scavenged from water bodies by fine-grained particles and that this property may offer an effective method of stripping these toxins from drinking water supplies.

\section{Conclusions}

Table 1 summarizes the variety of pollutants treated with different types of clays, their efficiency, and the effect of different variables on their adsorption capacity. From the table, it is clear that natural clay and its composites are capable of removing contaminants ranging from metals to priority pollutants from contaminated drinking water and its sources. Results from the recent advances in using natural clay and its modified composites show the flexible nature of the clay and its ecofriendly nature. They are capable of removing organic and inorganic contaminants from drinking water with very high removal ratios of toxic trace metals, nutrients, and organic matter. In most of the cases, they proved to be better or comparable with the existing commercial filter materials, adsorbents, and conventional methods used for decontamination of drinking water. Being natural and their abundance presence makes them a low-cost green, nontoxic adsorbent which can be used for removal of different contaminants from water and making clean and pure drinking water available for developed and developing nations.

\section{Future Directions}

The use of clay materials with natural polymer coating holds great promise for water treatment. As mentioned above, the adsorption capacity of natural and modified clay minerals increases with the coating of polymer on them. More research is needed to get abundant results in using the hybrid clay and polymeric materials in water treatment. Another research which needs immediate attention involves using clay for successful removal of emerging contaminants present in trace amount in our drinking water. Present conventional water treatment technologies are incapable of removing the emerging contaminants. Currently, the research in this field is scarce. But the available research results hold significant promise for the use of modified clay materials for emerging contaminant treatment without undesired toxic effects to the ecosystem.

$\begin{array}{ll}\text { Abbreviation } \\ \text { Al: } & \text { Aluminum } \\ \text { Si: } & \text { Silicon } \\ \text { O: } & \text { Oxygen } \\ \text { FTIR: } & \begin{array}{l}\text { Fourier transform infrared } \\ \text { spectroscopy }\end{array} \\ \text { DTA-TG: } & \text { Differential thermal analysis and } \\ & \text { thermal gravimetric analysis } \\ \text { U: } & \text { Uranium } \\ \text { mg/L: } & \text { Milligram per Liter } \\ K_{d}: & \text { Dissociation constant } \\ \text { g/L: } & \text { Grams per Liter } \\ \text { Cr: } & \text { Chromium } \\ \text { Fe: } & \text { Iron } \\ \text { Mn: } & \text { Manganese } \\ \text { As: } & \text { Arsenic } \\ \text { mgg }{ }^{-1}: & \text { Milligrams per gram } \\ \mu \mathrm{g:} & \text { Microgram } \\ \text { Cd: } & \text { Cadmium } \\ \text { Cu: } & \text { Copper } \\ \text { Hg: } & \text { Mercury } \\ \text { Pb: } & \text { Lead } \\ \text { Zn: } & \text { Zinc } \\ \text { As: } & \text { Arsenic } \\ \text { EU: } & \text { European Union } \\ \text { EPA: } & \text { Environment Protection Agency } \\ \text { ppb: } & \text { Parts per billion } \\ \text { mM: } & \text { Millimolar } \\ \text { WHO: } & \text { World Health organization } \\ \text { XRD: } & \text { X-Ray Diffraction } \\ \text { XPS: } & \text { X-ray photoelectron spectroscopy } \\ & \end{array}$




$\begin{array}{ll}\mathrm{NaOH}: & \text { Sodium hydroxide } \\ \mathrm{M}: & \text { Molar } \\ \mathrm{La}: & \text { Lanthanum } \\ \mathrm{Mg}: & \text { Magnesium } \\ \mathrm{Zr}: & \text { Zirconium } \\ \mathrm{Ca}: & \text { Calcium } \\ \mathrm{HCl}: & \text { Hydrochloric acid } \\ \mathrm{H}_{2} \mathrm{SO}_{4}: & \text { Sulphuric acid } \\ \mathrm{BET} \mathrm{Isotherm} & \text { Stephen Brunauer, Paul Hugh } \\ & \text { Emmett, and Edward Teller theory } \\ \mathrm{KCl}: & \text { Potassium chloride } \\ \mathrm{Co}: & \text { Cobalt } \\ \mathrm{Ni}: & \text { Nickel. }\end{array}$

\section{Acknowledgments}

The author is grateful to Ms. Melanie Magre for her review comments on the initial draft of the paper. The author also wants to thank the reviewer for useful comments to improve the paper. The author is grateful to Professor Thomas J. Gerik for providing financial support for the publication of this paper.

\section{References}

[1] The Clay Mineral Group, 2011, http://mineral.galleries.com/ minerals/silicate/clays.htm.

[2] S. H. Lin and R. S. Juang, "Heavy metal removal from water by sorption using surfactant-modified montmorillonite," Journal of Hazardous Materials B, vol. 92, no. 3, pp. 315-326, 2002.

[3] B. S. Krishna, D. S. R. Murty, and B. S. Jai Prakash, "Thermodynamics of chromium(VI) anionic species sorption onto surfactant-modified montmorillonite clay," Journal of Colloid and Interface Science, vol. 229, no. 1, pp. 230-236, 2000.

[4] S. E. Bailey, T. J. Olin, R. M. Bricka, and D. D. Adrian, "A review of potentially low-cost sorbents for heavy metals," Water Research, vol. 33, no. 11, pp. 2469-2479, 1999.

[5] S. Babel and T. A. Kurniawan, "Low-cost adsorbents for heavy metals uptake from contaminated water: a review," Journal of Hazardous Materials B, vol. 97, no. 1-3, pp. 219243, 2003.

[6] R. L. Virta, U.S. Geological Survey-Minerals Information, 1996, http://minerals.usgs.gov/minerals/pubs/commodity/ 190496.pdf.

[7] T. J. Pinnavaia, "Intercalated clay catalysts," Science, vol. 220, no. 4595, pp. 365-371, 1983.

[8] F. Cadena, R. Rizvi, and R. W. Peters, "Feasibility studies for the removal of heavy metal from solution using tailored bentonite, hazardous and industrial wastes," in Proceedings of the 22nd Mid-Atlantic Industrial Waste Conference, pp. 77-94, Drexel University, July 1990.

[9] K. Tanabe, "Solid acid and base catalysis," in CatalysisScience and Technology, J. R. Anderson and M. Boudart, Eds., p. 231, Springer, New York, NY, USA, 1981.

[10] H. van Olphen, An Introduction to Clay Colloid Chemistry, Wiley Interscience, New York, NY, USA, 2nd edition, 1977.

[11] K. G. Bhattacharyya and S. Sen Gupta, "Adsorption of a few heavy metals on natural and modified kaolinite and montmorillonite: a review," Advances in Colloid and Interface Science, vol. 140, no. 2, pp. 114-131, 2008.
[12] W. Wang, A. Li, J. Zhang, and A. Wang, "Study on superabsorbent composite: XI. Effect of thermal treatment and acid activation of attapulgite on water absorbency of poly(acrylic acid)/attapulgite superabsorbent composite," Polymer Composites, vol. 28, no. 3, pp. 397-404, 2007.

[13] A. Li, J. Zhang, and A. Wang, "Preparation and slow-release property of a poly(acrylic acid)/attapulgite/sodium humate superabsorbent composite," Journal of Applied Polymer Science, vol. 103, no. 1, pp. 37-45, 2007.

[14] S. Ekici, Y. Işıkver, and D. Saraydın, "Poly (acrylamide-sepiolite) composite hydrogels: preparation, swelling and dye adsorption properties," Polymer Bulletin, vol. 57, no. 2, pp. 231241, 2006.

[15] E. M. Araújo, T. J. A. Mélo, L. N. L. Santana et al., "The influence of organo-bentonite clay on the processing and mechanical properties of nylon 6 and polystyrene composites," Materials Science and Engineering B, vol. 112, no. 2-3, pp. 175-178, 2004.

[16] S. Pandey and S. B. Mishra, "Organic-inorganic hybrid of chitosan/organoclay bionanocomposites for hexavalent chromium uptake," Journal of Colloid and Interface Science, vol. 361, no. 2, pp. 509-520, 2011.

[17] G. J. Churchman, "Formation of complexes between bentonite and different cationic polyelectrolytes and their use as sorbents for non-ionic and anionic pollutants," Applied Clay Science, vol. 21, no. 3-4, pp. 177-189, 2002.

[18] C. Breen, "The characterisation and use of polycationexchanged bentonites," Applied Clay Science, vol. 15, no. 1-2, pp. 187-219, 1999.

[19] A. Radian and Y. G. Mishael, "Characterizing and designing polycation-clay nanocomposites as a basis for imazapyr controlled release formulations," Environmental Science and Technology, vol. 42, no. 5, pp. 1511-1516, 2008.

[20] D. Zadaka, S. Nir, A. Radian, and Y. G. Mishael, "Atrazine removal from water by polycation-clay composites: effect of dissolved organic matter and comparison to activated carbon," Water Research, vol. 43, no. 3, pp. 677-683, 2009.

[21] M. Darder, M. Colilla, and E. Ruiz-Hitzky, "Chitosan-clay nanocomposites: application as electrochemical sensors," Applied Clay Science, vol. 28, no. 1-4, pp. 199-208, 2005.

[22] M. Darder, M. López-Blanco, P. Aranda, A. J. Aznar, J. Bravo, and E. Ruiz-Hitzky, "Microfibrous chitosan-sepiolite nanocomposites," Chemistry of Materials, vol. 18, no. 6, pp. 1602-1610, 2006.

[23] E. Ruiz-Hitzky, M. Darder, and P. Aranda, "Functional biopolymer nanocomposites based on layered solids," Journal of Materials Chemistry, vol. 15, no. 35-36, pp. 3650-3662, 2005.

[24] J. H. An and S. Dultz, "Adsorption of tannic acid on chitosanmontmorillonite as a function of $\mathrm{pH}$ and surface charge properties," Applied Clay Science, vol. 36, no. 4, pp. 256-264, 2007.

[25] J. M. Li, X. G. Meng, C. W. Hu, and J. Du, "Adsorption of phenol, p-chlorophenol and p-nitrophenol onto functional chitosan," Bioresource Technology, vol. 100, no. 3, pp. 11681173, 2009.

[26] S. Sen Gupta and K. G. Bhattacharyya, "Removal of Cd(II) from aqueous solution by kaolinite, montmorillonite and their poly(oxo zirconium) and tetrabutylammonium derivatives," Journal of Hazardous Materials, vol. 128, no. 2-3, pp. 247-257, 2006.

[27] M. Ulmanu, E. Marañón, Y. Fernández, L. Castrillón, I. Anger, and D. Dumitriu, "Removal of copper and cadmium ions from diluted aqueous solutions by low cost and waste 
material adsorbents," Water, Air, and Soil Pollution, vol. 142, no. 1-4, pp. 357-373, 2003.

[28] K. G. Bhattacharyya and S. Sen Gupta, "Adsorption of chromium(VI) from water by clays," Industrial and Engineering Chemistry Research, vol. 45, no. 21, pp. 7232-7240, 2006.

[29] O. Yavuz, Y. Altunkaynak, and F. Guzel, "Removal of copper, nickel, cobalt and manganese from aqueous solution by kaolinite," Water Research, vol. 37, no. 4, pp. 948-952, 2003.

[30] K. G. Bhattacharyya and S. Sen Gupta, "Adsorption of Co(II) from aqueous medium on natural and acid activated kaolinite and montmorillonite," Separation Science and Technology, vol. 42, no. 15, pp. 3391-3418, 2007.

[31] S. H. Lin and R. S. Juang, "Heavy metal removal from water by sorption using surfactant-modified montmorillonite," Journal of Hazardous Materials B, vol. 92, no. 3, pp. 315-326, 2002.

[32] K. G. Bhattacharyya and S. Sen Gupta, "Influence of acid activation on adsorption of $\mathrm{Ni}(\mathrm{II})$ and $\mathrm{Cu}$ (II) on kaolinite and montmorillonite: kinetic and thermodynamic study," Chemical Engineering Journal, vol. 136, no. 1, pp. 1-13, 2008.

[33] K. G. Bhattacharyya and S. Sen Gupta, "Adsorption of Fe(III) from water by natural and acid activated clays: studies on equilibrium isotherm, kinetics and thermodynamics of interactions," Adsorption, vol. 12, no. 3, pp. 185-204, 2006.

[34] S. Sen Gupta and K. G. Bhattacharyya, "Interaction of metal ions with clays: I. A case study with $\mathrm{Pb}(\mathrm{II})$, , Applied Clay Science, vol. 30, no. 3-4, pp. 199-206, 2005.

[35] K. G. Bhattacharyya and S. Sen Gupta, "Pb(II) uptake by kaolinite and montmorillonite in aqueous medium: influence of acid activation of the clays," Colloids and Surfaces A, vol. 277, no. 1-3, pp. 191-200, 2006.

[36] S. Sen Gupta and K. G. Bhattacharyya, "Adsorption of Ni(II) on clays," Journal of Colloid and Interface Science, vol. 295, no. 1, pp. 21-32, 2006.

[37] A. Mellah and S. Chegrouche, "The removal of zinc from aqueous solutions by natural bentonite," Water Research, vol. 31, no. 3, pp. 621-629, 1997.

[38] L. C. A. Oliveira, R. V. R. A. Rios, J. D. Fabris, K. Sapag, V. K. Garg, and R. M. Lago, "Clay-iron oxide magnetic composites for the adsorption of contaminants in water," Applied Clay Science, vol. 22, no. 4, pp. 169-177, 2003.

[39] Ö. Etci, N. Bektaş, and M. S. Öncel, "Single and binary adsorption of lead and cadmium ions from aqueous solution using the clay mineral beidellite," Environmental Earth Sciences, vol. 61, no. 2, pp. 231-240, 2010.

[40] H. Gecol, P. Miakatsindila, E. Ergican, and R. H. Sage, "Biopolymer coated clay particles for the adsorption of tungsten from water," Desalination, vol. 197, no. 1-3, pp. 165-178, 2006.

[41] S. Aytas, M. Yurtlu, and R. Donat, "Adsorption characteristic of U(VI) ion onto thermally activated bentonite," Journal of Hazardous Materials, vol. 172, no. 2-3, pp. 667-674, 2009.

[42] P. C. Mishra and R. K. Patel, "Removal of lead and zinc ions from water by low cost adsorbents," Journal of Hazardous Materials, vol. 168, no. 1, pp. 319-325, 2009.

[43] P. Yuan, M. Fan, D. Yang et al., "Montmorillonite-supported magnetite nanoparticles for the removal of hexavalent chromium $[\mathrm{Cr}(\mathrm{VI})]$ from aqueous solutions," Journal of Hazardous Materials, vol. 166, no. 2-3, pp. 821-829, 2009.

[44] Y. S. Kang, S. Risbud, J. F. Rabolt, and P. Stroeve, "Synthesis and characterization of nanometer-size $\mathrm{Fe}_{3} \mathrm{O}_{4}$ and $\gamma$ - $\mathrm{Fe}_{2} \mathrm{O}_{3}$ particles," Chemistry of Materials, vol. 8, no. 9, pp. 22092211, 1996.
[45] M. J. Angove, B. B. Johnson, and J. D. Wells, "The influence of temperature on the adsorption of cadmium(II) and cobalt(II) on kaolinite," Journal of Colloid and Interface Science, vol. 204, no. 1, pp. 93-103, 1998.

[46] B. Doušová, L. Fuitová, T. Grygar et al., "Modified aluminosilicates as low-cost sorbents of As(III) from anoxic groundwater," Journal of Hazardous Materials, vol. 165, no. 1-3, pp. 134-140, 2009.

[47] J. Fang, B. Deng, and T. M. Whitworth, "Arsenic removal from drinking water using clay membranes," ACS Symposium Series, vol. 915, pp. 294-305, 2006.

[48] S. M. I. Sajidu, I. Persson, W. R. L. Masamba, E. M. T. Henry, and D. Kayambazinthu, "Removal of $\mathrm{Cd}^{2+}, \mathrm{Cr}^{3+}, \mathrm{Cu}^{2+}, \mathrm{Hg}^{2+}$, $\mathrm{Pb}^{2+}$ and $\mathrm{Zn}^{2+}$ cations and $\mathrm{AsO}_{4}^{3-}$ anions from aqueous solutions by mixed clay from Tundulu in Malawi and characterisation of the clay," Water SA, vol. 32, no. 4, pp. 519-526, 2006.

[49] D. Peak, U. K. Saha, and P. M. Huang, "Selenite adsorption mechanisms on pure and coated montmorillonite: an EXAFS and XANES spectroscopic study," Soil Science Society of America Journal, vol. 70, no. 1, pp. 192-203, 2006.

[50] N. Zhang, L. S. Lin, and D. Gang, "Adsorptive selenite removal from water using iron-coated GAC adsorbents," Water Research, vol. 42, no. 14, pp. 3809-3816, 2008.

[51] D. G. Barceloux, "Selenium," Journal of Toxicology-Clinical Toxicology, vol. 37, no. 2, pp. 145-172, 1999.

[52] N. Bleiman and Y. G. Mishael, "Selenium removal from drinking water by adsorption to chitosan-clay composites and oxides: Batch and columns tests," Journal of Hazardous Materials, vol. 183, no. 1-3, pp. 590-595, 2010.

[53] P. Na, X. Jia, B. Yuan et al., "Arsenic adsorption on Ti-pillared montmorillonite," Journal of Chemical Technology and Biotechnology, vol. 85, no. 5, pp. 708-714, 2010.

[54] C. L. Ake, K. Mayura, H. Huebner, G. R. Bratton, and T. D. Phillips, "Development of porous clay-based composites for the sorption of lead from water," Journal of Toxicology and Environmental Health A, vol. 63, no. 6, pp. 459-475, 2001.

[55] G. Zhao, H. Zhang, Q. Fan et al., "Sorption of copper(II) onto super-adsorbent of bentonite-polyacrylamide composites," Journal of Hazardous Materials, vol. 173, no. 1-3, pp. 661-668, 2010.

[56] Y. Bulut, G. Akçay, D. Elma, and I. E. Serhatlı, "Synthesis of clay-based superabsorbent composite and its sorption capability," Journal of Hazardous Materials, vol. 171, no. 1-3, pp. 717-723, 2009.

[57] D. Thakre, S. Rayalu, R. Kawade, S. Meshram, J. Subrt, and N. Labhsetwar, "Magnesium incorporated bentonite clay for defluoridation of drinking water," Journal of Hazardous Materials, vol. 180, no. 1-3, pp. 122-130, 2010.

[58] S. P. Kamble, P. Dixit, S. S. Rayalu, and N. K. Labhsetwar, "Defluoridation of drinking water using chemically modified bentonite clay," Desalination, vol. 249, no. 2, pp. 687-693, 2009.

[59] Y. X. Ma, F. M. Shi, X. L. Zheng, J. Ma, and J. M. Yuan, "Defluoridation from aqueous solutions by Zr-loaded bentonite," Journal of Harbin Institute of Technology (New Series), vol. 12, supplement 1, pp. 224-229, 2005.

[60] C. J. Mena-Duran, M. R. Sun Kou, T. Lopez et al., "Nitrate removal using natural clays modified by acid thermoactivation," Applied Surface Science, vol. 253, no. 13, pp. 5762-5766, 2007.

[61] L. Gu, X. Yu, J. Xu, L. Lv, and Q. Wang, "Removal of dichloroacetic acid from drinking water by using adsorptive ozonation," Ecotoxicology, vol. 20, no. 5, pp. 1160-1166, 2011. 
[62] J. Lu and J. Pan, "Removal of carbon tetrachloride from contaminated groundwater environment by adsorption method," in Proceedings of the 4th International Conference on Bioinformatics and Biomedical Engineering (iCBBE '10), Chengdu, China, June 2010.

[63] S. M. Rivera-Jimenez, M. M. Lehner, W. A. Cabrera-Lafaurie, and A. J. Hernández-Maldonado, "Removal of naproxen, salicylic acid, clofibric acid, and carbamazepine by water phase adsorption onto inorganic-organic-intercalated bentonites modified with transition metal cations," Environmental Engineering Science, vol. 28, no. 3, pp. 171-182, 2011.

[64] H. B. Senturk, D. Ozdes, A. Gundogdu, C. Duran, and M. Soylak, "Removal of phenol from aqueous solutions by adsorption onto organomodified Tirebolu bentonite: equilibrium, kinetic and thermodynamic study," Journal of Hazardous Materials, vol. 172, no. 1, pp. 353-362, 2009.

[65] L. Gu, X. Zhang, L. Lei, and X. Liu, "Concurrent removal of humic acid and o-dichlorobenzene in drinking water by combined ozonation and bentonite coagulation process," Water Science and Technology, vol. 60, no. 12, pp. 3061-3068, 2009.

[66] J. Q. Jiang and C. G. Kim, "Comparison of algal removal by coagulation with clays and Al-based coagulants," Separation Science and Technology, vol. 43, no. 7, pp. 1677-1686, 2008.

[67] Z. Gao, X. Peng, H. Zhang, Z. Luan, and B. Fan, "Montmorillonite- $\mathrm{Cu}(\mathrm{II}) / \mathrm{Fe}(\mathrm{III})$ oxides magnetic material for removal of cyanobacterial Microcystis aeruginosa and its regeneration," Desalination, vol. 247, no. 1-3, pp. 337-345, 2009.

[68] D. Zadaka, S. Nir, A. Radian, and Y. G. Mishael, "Atrazine removal from water by polycation-clay composites: effect of dissolved organic matter and comparison to activated carbon," Water Research, vol. 43, no. 3, pp. 677-683, 2009.

[69] T. Undabeytia, S. Nir, T. Sánchez-Verdejo, J. Villaverde, C. Maqueda, and E. Morillo, "A clay-vesicle system for water purification from organic pollutants," Water Research, vol. 42, no. 4-5, pp. 1211-1219, 2008.

[70] G. Rytwo, Y. Kohavi, I. Botnick, and Y. Gonen, "Use of CVand TPP-montmorillonite for the removal of priority pollutants from water," Applied Clay Science, vol. 36, no. 1-3, pp. 182-190, 2007.

[71] F. P. Bonina, M. L. Giannossi, L. Medici, C. Puglia, V. Summa, and F. Tateo, "Adsorption of salicylic acid on bentonite and kaolin and release experiments," Applied Clay Science, vol. 36, no. 1-3, pp. 77-85, 2007.

[72] T. Wang, R. L. Zhu, F. Ge, J. X. Zhu, H. P. He, and W. X. Chen, "Sorption of phenol and nitrobenzene in water by CTMAB/CPAM organobentonites," Huanjing Kexue/Environmental Science, vol. 31, no. 2, pp. 385-389, 2010.

[73] W. Zhang, Y. Ding, S. A. Boyd, B. J. Teppen, and H. Li, "Sorption and desorption of carbamazepine from water by smectite clays," Chemosphere, vol. 81, no. 7, pp. 954-960, 2010.

[74] R. J. Morris, D. E. Williams, H. A. Luu, C. F. B. Holmes, R. J. Andersen, and S. E. Calvert, "The adsorption of microcystinLR by natural clay particles,” Toxicon, vol. 38, no. 2, pp. 303308, 2000.

[75] A. K. Chaturvedi, K. P. Yadava, K. C. Pathak, and V. N. Singh, "Defluoridation of water by adsorption on fly ash," Water, Air, and Soil Pollution, vol. 49, no. 1-2, pp. 41-69, 1990.

[76] M. G. Sujana, R. S. Thakur, and S. B. Rao, "Removal of fluoride from aqueous solution by using alum sludge," Journal of Colloid and Interface Science, vol. 206, no. 1, pp. 94-101, 1998.
[77] A. Toyoda and T. Taira, "A new method for treating fluorine wastewater to reduce sludge and running costs," IEEE Transactions on Semiconductor Manufacturing, vol. 13, no. 3, pp. 305-309, 2000.

[78] S. Ayoob and A. K. Gupta, "Fluoride in drinking water: a review on the status and stress effects," Critical Reviews in Environmental Science and Technology, vol. 36, no. 6, pp. 433487, 2006.

[79] WHO (World Health Organization), Fluorine and Fluorides, Environmental Health Criteria, Geneva, Switzerland, World Health Organization, 1984.

[80] H. H. Murray, "Traditional and new applications for kaolin, smectite, and palygorskite: a general overview," Applied Clay Science, vol. 17, no. 5-6, pp. 207-221, 2000.

[81] M. Sanchez Camazano and M. J. Sanchez Martin, "Factors influencing interactions of organophosphorus pesticides with montmorillonite," Geoderma, vol. 29, no. 2, pp. 107$118,1983$.

[82] C. C. Ainsworth, J. M. Zachara, and R. L. Schmidt, "Quinoline sorption on Na-montmorillonite: contributions of the protonated and neutral species," Clays \& Clay Minerals, vol. 35, no. 2, pp. 121-128, 1987.

[83] J. M. Rodriguez, A. J. Lopez, and S. Bruque, "Interaction of phenamiphos with montmorillonite," Clays \& Clay Minerals, vol. 36, no. 3, pp. 284-288, 1988.

[84] H. T. Shu, D. Li, A. A. Scala, and Y. H. Ma, "Adsorption of small organic pollutants from aqueous streams by aluminosilicate-based microporous materials," Separation and Purification Technology, vol. 11, no. 1, pp. 27-36, 1997.

[85] A. Torrents and S. Jayasundera, "The sorption of nonionic pesticides onto clays and the influence of natural organic carbon," Chemosphere, vol. 35, no. 7, pp. 1549-1565, 1997.

[86] T. G. Danis, T. A. Albanis, D. E. Petrakis, and P. J. Pomonis, "Removal of chlorinated phenols from aqueous solutions by adsorption on alumina pillared clays and mesoporous alumina aluminum phosphates," Water Research, vol. 32, no. 2, pp. 295-302, 1998.

[87] I. K. Konstantinou, T. A. Albanis, D. E. Petrakis, and P. J. Pomonis, "Removal of herbicides from aqueous solutions by adsorption on Al-pillared clays, Fe-Al pillared clays and mesoporous alumina aluminum phosphates," Water Research, vol. 34, no. 12, pp. 3123-3136, 2000.

[88] D. Sun, W. Cai, C. Shi, X. Mu, Y. Song, and H. Qi, "Advanced oxidations of chloroacetic acids present in drinking water," Journal of Environmental Science and Health A, vol. 35, no. 10, pp. 1811-1816, 2000.

[89] M. G. Pervova, V. E. Kirichenko, and K. I. Pashkevich, "Determination of chloroacetic acids in drinking water by reaction gas chromatography," Journal of Analytical Chemistry, vol. 57, no. 4, pp. 326-330, 2002.

[90] World Health Organization, Guideline for Safe Recreational Water Environments 1, Coastal and Fresh Water, WHO, Geneva, Switzerland, 2003.

[91] Health Canada, Summary of Guideline for Canadian Drinking Water Quality, Federal Provincial Territorial Committee on Drinking Water, Ottawa, Canada, 2003.

[92] American Public Health Association/American Water Works Association/Water Environmental Federation, Standard Methods for the Examination of Water and Wastewater, Washington, DC, USA, 20th edition, 1998.

[93] T. Kiely, D. Donaldson, and A. Grube, Pesticide Industry Sales and Usage: 2000 and 2001 Market Estimates, U.S. Environmental Protection Agency, Washington, DC, USA, 2004. 
[94] N. Graziano, M. J. Mcguire, A. Roberson, C. Adams, H. Jiang, and N. Blute, "2004 national atrazine occurrence monitoring program using the abraxis ELISA method," Environmental Science and Technology, vol. 40, no. 4, pp. 1163-1171, 2006.

[95] M. J. Cerejeira, P. Viana, S. Batista et al., "Pesticides in Portuguese surface and ground waters," Water Research, vol. 37, no. 5, pp. 1055-1063, 2003.

[96] A. Papastergiou and E. Papadopoulou-Mourkidou, "Occurrence and spatial and temporal distribution of pesticide residues in groundwater of major corn-growing areas of Greece (1996-1997)," Environmental Science and Technology, vol. 35, no. 1, pp. 63-69, 2001.

[97] J. M. S. van Maanen, M. A. J. de Vaan, A. W. F. Veldstra, and W. P. A. M. Hendrix, "Pesticides and nitrate in groundwater and rainwater in the Province of Limburg in the Netherlands," Environmental Monitoring and Assessment, vol. 72, no. 1, pp. 95-114, 2001.

[98] J. B. Sass and A. Colangelo, "European Union bans atrazine, while the United States negotiates continued use," International Journal of Occupational and Environmental Health, vol. 12, no. 3, pp. 260-267, 2006.

[99] J. Lemić, D. Kovačević, M. Tomašević-Čanović, D. Kovačević, T. Stanić, and R. Pfend, "Removal of atrazine, lindane and diazinone from water by organo-zeolites," Water Research, vol. 40, no. 5, pp. 1079-1085, 2006.

[100] M. J. Sanchez-Martin, M. S. Rodriguez-Cruz, M. S. Andrades, and M. Sanchez-Camazano, "Efficiency of different clay minerals modified with a cationic surfactant in the adsorption of pesticides: influence of clay type and pesticide hydrophobicity," Applied Clay Science, vol. 31, no. 3-4, pp. 216-228, 2006.

[101] M. Borisover, E. R. Graber, F. Bercovich, and Z. Gerstl, "Suitability of dye-clay complexes for removal of non-ionic organic compounds from aqueous solutions," Chemosphere, vol. 44, no. 5, pp. 1033-1040, 2001.

[102] G. Abate and J. C. Masini, "Adsorption of atrazine, hydroxyatrazine, deethylatrazine, and deisopropylatrazine onto $\mathrm{Fe}(\mathrm{III})$ polyhydroxy cations intercalated vermiculite and montmorillonite," Journal of Agricultural and Food Chemistry, vol. 53, no. 5, pp. 1612-1619, 2005.

[103] M. Streat and L. A. Sweetland, "Removal of pesticides from water using hyper cross linked polymer phases: part 2Sorption studies," Process Safety and Environmental Protection, vol. 76, pp. 127-134, 1998.

[104] G. J. Churchman, "Formation of complexes between bentonite and different cationic polyelectrolytes and their use as sorbents for non-ionic and anionic pollutants," Applied Clay Science, vol. 21, no. 3-4, pp. 177-189, 2002.

[105] C. Breen, "The characterisation and use of polycation-exchanged bentonites," Applied Clay Science, vol. 15, no. 1-2, pp. 187-219, 1999.

[106] A. Radian and Y. G. Mishael, "Characterizing and designing polycation-clay nanocomposites as a basis for imazapyr controlled release formulations," Environmental Science and Technology, vol. 42, no. 5, pp. 1511-1516, 2008.

[107] W. W. Carmichael, "Freshwater cyanobacteria (blue-green algal) toxins," in Natural Toxins: Characterization, Pharmacology and Therapeutics, C. L. Ownby and G. V. Odell, Eds., pp. 3-16, Pergamon Press, London, UK, 1988.

[108] P. Cohen and P. T. W. Cohen, "Protein phosphatases come of age," Journal of Biological Chemistry, vol. 264, no. 36, pp. 21435-21438, 1989.
[109] S. Yoshizawa, R. Matsushima, M. F. Watanabe et al., "Inhibition of protein phosphatases by microcystis and nodularin associated with hepatotoxicity," Journal of Cancer Research and Clinical Oncology, vol. 116, no. 6, pp. 609-614, 1990.

[110] R. E. Honkanen, J. Zwiller, R. E. Moore et al., "Characterization of microcystin-LR, a potent inhibitor of type 1 and type 2A protein phosphatases," Journal of Biological Chemistry, vol. 265, no. 32, pp. 19401-19404, 1990.

[111] C. MacKintosh, K. A. Beattie, S. Klumpp, P. Cohen, and G. A. Codd, "Cyanobacterial microcystin-LR is a potent and specific inhibitor of protein phosphatases 1 and 2A from both mammals and higher plants," FEBS Letters, vol. 264, no. 2, pp. 187-192, 1990.

[112] R. Nishiwaki-Matsushima, S. Nishiwaki, T. Ohta et al., "Structure-function relationships of microcystins, liver tumor promoters, in interaction with protein phosphatase," Japanese Journal of Cancer Research, vol. 82, no. 9, pp. 993-996, 1991.

[113] R. Nishiwaki-Matsushima, T. Ohta, S. Nishiwaki et al., "Liver tumor promotion by the cyanobacterial cyclic peptide toxin microcystin-LR," Journal of Cancer Research and Clinical Oncology, vol. 118, no. 6, pp. 420-424, 1992.

[114] H. Fujiki and M. Suganuma, "Tumor promotion by inhibitors of protein phosphatases 1 and 2A: the okadaic acid class of compounds," Advances in Cancer Research, vol. 61, pp. 143-194, 1993.

[115] L. A. Lawton, B. J. P. A. Cornish, and A. W. R. MacDonald, "Removal of cyanobacterial toxins (microcystins) and cyanobacterial cells from drinking water using domestic water filters," Water Research, vol. 32, no. 3, pp. 633-638, 1998.

[116] K. I. Harada and K. Tsuji, "Persistence and decomposition of hepatotoxic microcystins produced by cyanobacteria in natural environment," Journal of Toxicology-Toxin Reviews, vol. 17, no. 3, pp. 385-403, 1998. 

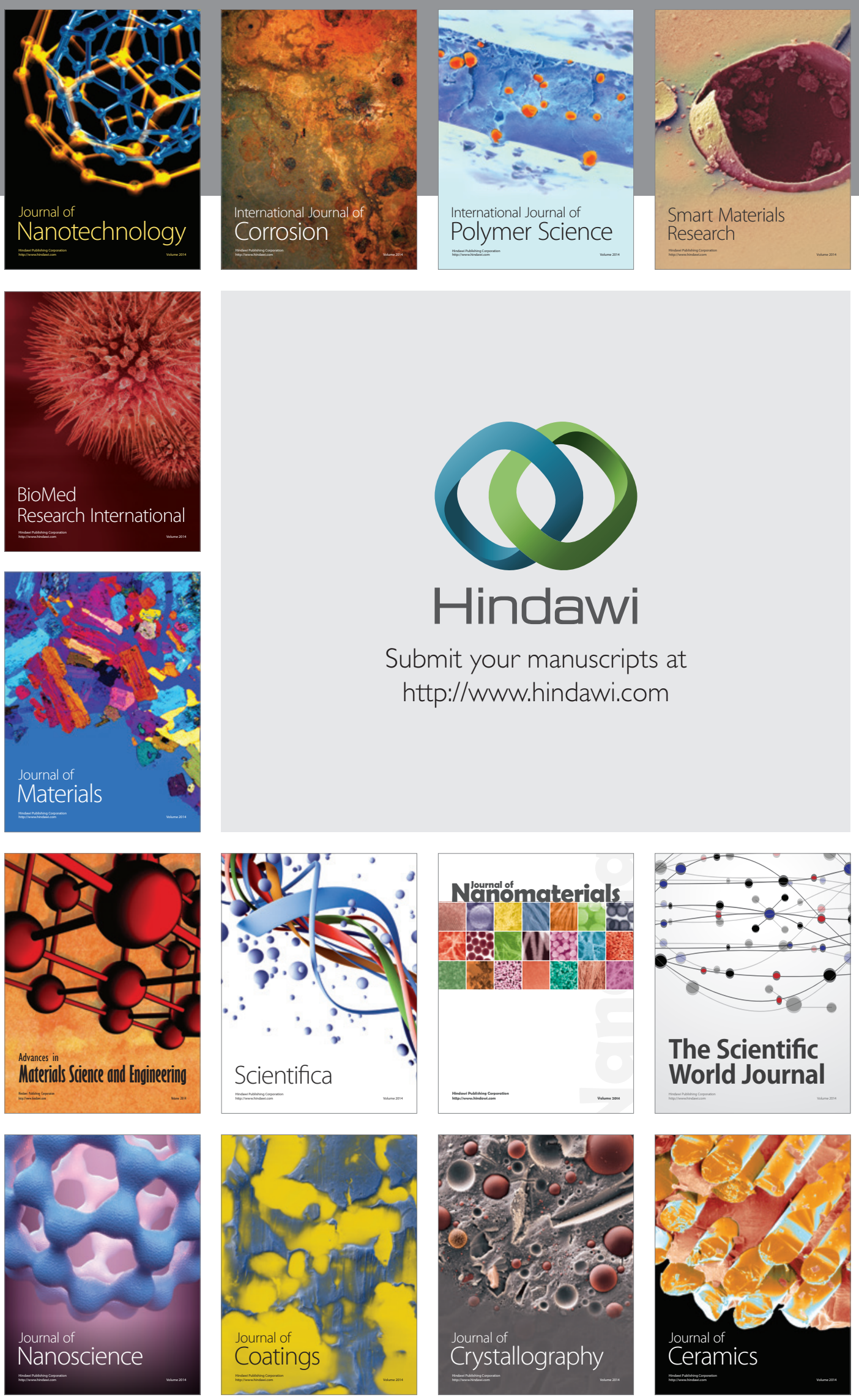

The Scientific World Journal

Submit your manuscripts at

http://www.hindawi.com

\section{World Journal}

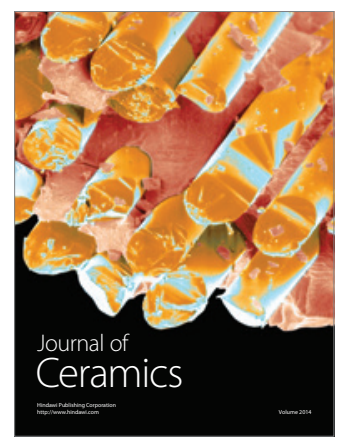

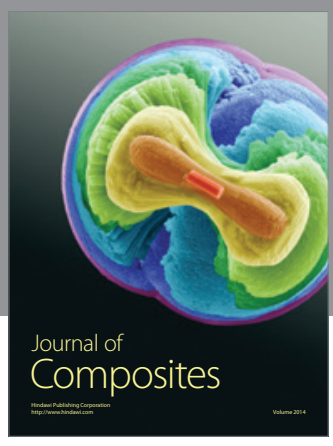
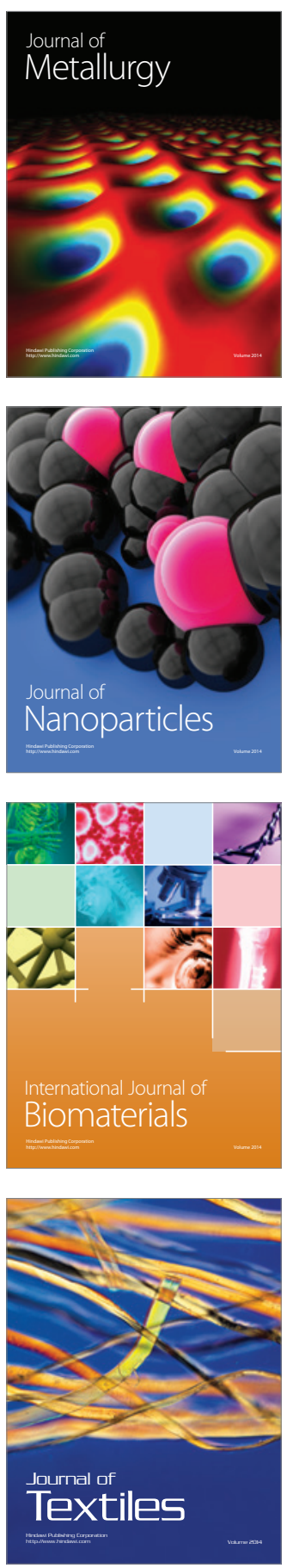